Review

\title{
Dietary Effects of Anthocyanins in Human Health: A Comprehensive Review
}

\author{
Ana C. Gonçalves ${ }^{1}{ }^{(\mathbb{D}}$, Ana R. Nunes ${ }^{1}$, Amílcar Falcão ${ }^{2,3}$, Gilberto Alves ${ }^{1}\left(\mathbb{D}\right.$ and Luís R. Silva ${ }^{1, * \mathbb{C}}$ \\ 1 CICS-UBI-Health Sciences Research Centre, University of Beira Interior, 6201-506 Covilhã, Portugal; \\ anacarolinagoncalves@sapo.pt (A.C.G.); araqueln@gmail.pt (A.R.N.); gilberto@fcsaude.ubi.pt (G.A.) \\ 2 CIBIT-Coimbra Institute for Biomedical Imaging and Translational Research, University of Coimbra, \\ Edifício do ICNAS, Pólo 3, Azinhaga de Santa Comba, 3000-548 Coimbra, Portugal; vr.amilcar.falcao@uc.pt \\ 3 Laboratory of Pharmacology, Faculty of Pharmacy, University of Coimbra, Pólo das Ciências da Saúde, \\ Azinhaga de Santa Comba, 3000-548 Coimbra, Portugal \\ * Correspondence: luisfarmacognosia@gmail.com; Tel.: +351-275-329-077
}

Citation: Gonçalves, A.C.; Nunes, A.R.; Falcão, A.; Alves, G.; Silva, L.R. Dietary Effects of Anthocyanins in Human Health: A Comprehensive Review. Pharmaceuticals 2021, 14, 690. https://doi.org/10.3390/ph14070690

Academic Editor: Noelia Duarte

Received: 25 June 2021

Accepted: 16 July 2021

Published: 18 July 2021

Publisher's Note: MDPI stays neutral with regard to jurisdictional claims in published maps and institutional affiliations.

Copyright: () 2021 by the authors. Licensee MDPI, Basel, Switzerland. This article is an open access article distributed under the terms and conditions of the Creative Commons Attribution (CC BY) license (https:// creativecommons.org/licenses/by/ $4.0 /)$.

\begin{abstract}
In recent years, the consumption of natural-based foods, including beans, fruits, legumes, nuts, oils, vegetables, spices, and whole grains, has been encouraged. This fact is essentially due to their content in bioactive phytochemicals, with the phenolic compounds standing out. Among them, anthocyanins have been a target of many studies due to the presence of catechol, pyrogallol, and methoxy groups in their chemical structure, which confer notable scavenging, anti-apoptotic, and anti-inflammatory activities, being already recommended as supplementation to mitigate or even attenuate certain disorders, such as diabetes, cancer, and cardiovascular and neurological pathologies. The most well-known anthocyanins are cyanidin 3-O-glucoside and cyanidin 3-O-rutinoside. They are widespread in nature, being present in considerable amounts in red fruits and red vegetables. Overall, the present review intends to discuss the most recent findings on the potential health benefits from the daily intake of anthocyanin-rich foods, as well as their possible pharmacological mechanisms of action. However, before that, some emphasis regarding their chemical structure, dietary sources, and bioavailability was done.
\end{abstract}

Keywords: anthocyanins; antioxidants; dietary source; bioavailability; biological activity; biosynthesis

\section{Introduction}

In the past few years, it is widely accepted that the daily intake of medicinal herbs, fruits, and vegetables provides a wide array of benefits to human health [1]. This fact is essentially due to their composition, plentiful in several non-nutrient bioactive compounds, such as phenolics, whose abilities to modulate different processes and pathways in the human body, such as regulating glucose levels and boosting antioxidant, anti-inflammatory, anti-mutagenic, anticancer, and neuroprotective effects, are already well-known [2,3].

Considering that nature-based products have been used since ancient times to treat several disorders, such as colds, pain, gastrointestinal aches, and hypertension, among others, it is not surprising that this tendency continues to increase worldwide [4]. A clear example is their incorporation into pharmaceutical products used in cancer therapy $[5,6]$. According to the database of 2019, from the 247 anticancer drugs available in the market, about $81.0 \%$ are derived from natural products; the remaining ones are synthetic drugs $(15.3 \%)$ or vaccines $(3.65 \%)$ [3].

Among the phenolic compounds, anthocyanidins and their conjugated acyl-glycosylated or glycosylated forms, called anthocyanins, are both members of the flavonoids and an interesting class of water-soluble vacuolar pigments [7]. They are synthetized via the flavonoid path and considered the major contributors to the vivid red, orange, violet, and blue colours exhibited by various edible flowers, vegetables, fruits, some cereals, seeds and plant leaves, and their derivatives, such as juices, tea, and red wines [8]. They also have received much 
attention owing to their nutritional value, pharmacokinetic profile, pharmacological mechanisms, and health-promoting properties $[9,10]$. Indeed, recent human and animals surveys revealed that they are functional compounds able to increase antioxidant defences, diminish free radical damage, chronic inflammation and the risk of mutations, and attenuate, or even mitigate, the development and progression of many non-communicable and degenerative chronic disorders, namely, atherosclerosis, metabolic syndrome, eye and kidney complications, many cancer types, and also to control weight [6,11-19]. These biological activities are associated with their chemical structure, the presence of the catechol and pyrogallol groups standing out, allowing them to have the ability to chelate metal ions and neutralize free radicals and reactive species [4,20-22]. The predominant ones found in foodstuffs are cyanidin, delphinidin, pelargonidin, peonidin, petunidin, and malvidin glycosides $[6,23,24]$.

This comprehensive review aimed to assess and elucidate the impact of anthocyanins and anthocyanin-rich foods on human health. For that, the first part of the manuscript focuses on a description regarding the chemical structure and function as well as main dietary sources of anthocyanins. Afterwards, the bioavailability and metabolism after intake are mentioned. Finally, we summarized and discussed the most recent literature regarding the main therapeutic effects of anthocyanins on different disorders.

\section{Chemical Structure and Function of Anthocyanins}

Phenolic compounds are secondary metabolites produced by plants to protect them against pathogens and predators, ultraviolet radiation, climate conditions, and acidified soils, acting also as attractants for pollinators, antifeedants, and phytoalexins [25,26]. They are also considered the main contributors to plants' colour, nutritional, and sensory characteristics [27]. Their structure presents at least one benzene ring coupled to one or more hydroxyl groups and can range from simple phenolic, low molecular weight and singlearomatic molecules to highly polymerized compounds [28]. In order to facilitate their distinction, phenolics are classified into two major groups: (i) non-flavonoid compounds (phenolic acids, tannins, lignans, coumarins, stilbenes, and curcuminoids) and (ii) flavonoid compounds (anthocyanidins, flavan-3-ols, and their oligomeric structures, recognized as proanthocyanidins, flavanones, flavanonols, flavones, flavonols, and isoflavones) $[7,25,26]$. Their biosynthesis, which is shown in Figure 1, comprises the shikimate, phenylpropanoid, and flavonoid pathways, and involves deamination, hydroxylation, and methylation reactions [25].

Concerning the flavonoids (Figure 2), they represent about two-thirds of the total dietary phenolics consumed, and currently, more than 9000 different flavonoids have been identified so far [29,30]. They all possess a common flavan nucleus, i.e., a 15 carbonstructure (C6 (A ring)-C3 (C ring)-C6 (B ring)), composed of 2 aromatic rings (A and B rings derived from the acetate/malonate and shikimate pathways, respectively), linked by a heterocyclic benzopyran 3-carbon ring that contains an oxygen atom ( $\mathrm{C}$ ring) $[26,31]$. However, they differ in (i) the $C$ ring unsaturation and oxidation state; (ii) A, B, and C ring substituents, such as the presence or absence of double bonds and carbonyl groups, and the possible occurrence of acylation, alkylation, glycosylation, oxygenation, and sulphonation processes; (iii) the position where the B ring is linked to the $\mathrm{C}$ ring; and (iv) location and number of hydroxy and methoxy groups on the B ring [26]. 


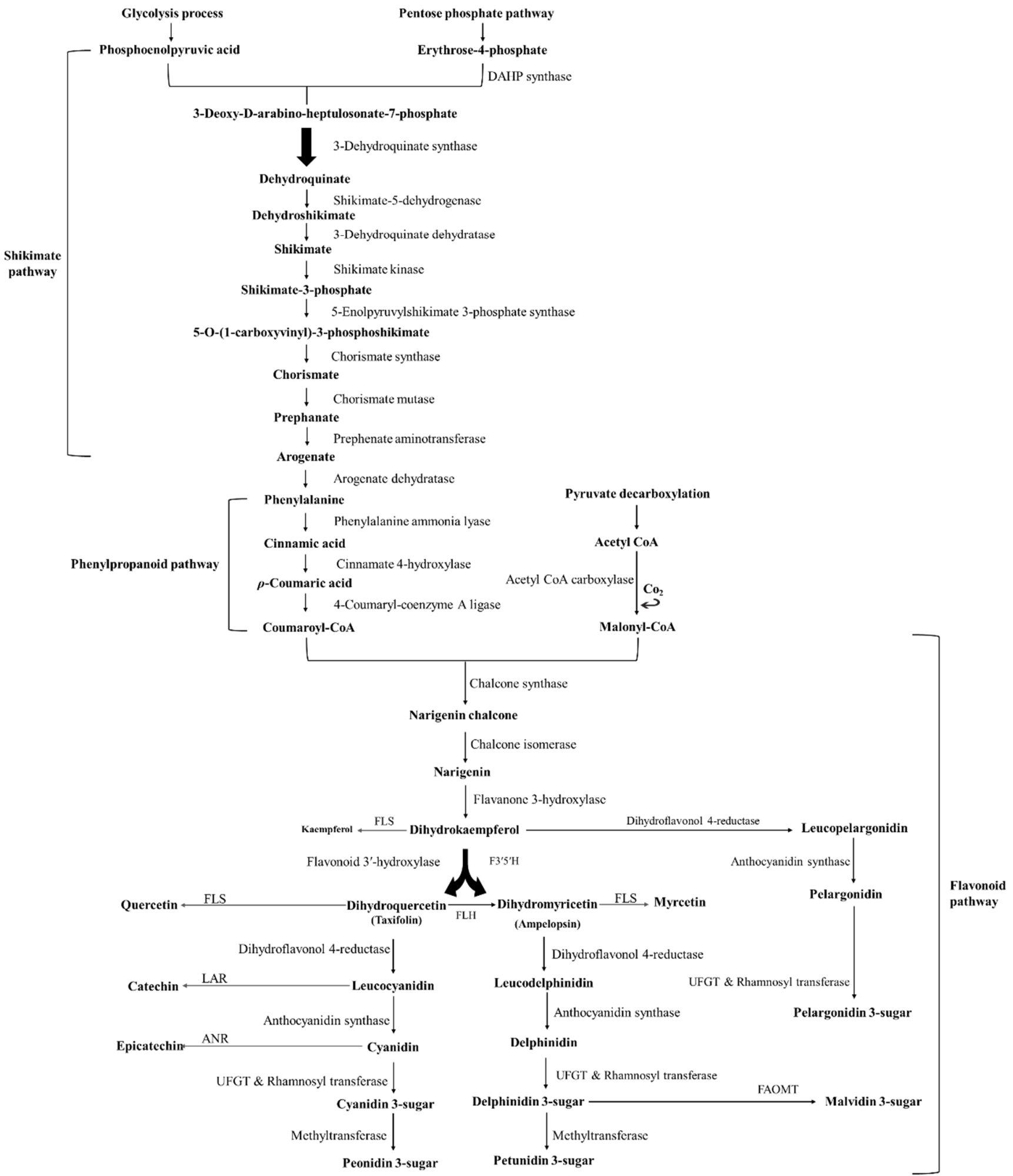

Figure 1. Biosynthesis pathways of the main anthocyanins found in foods. DAHP: 3-Deoxy-D-arabinoheptulosonate 7-phosphate; CoA: coenzyme A; F3'5'H: Flavonoid 3', 5'-hydroxylase; FLH: Flavanone 3-hydroxylase; FLS: Flavonol synthase; LAR: Leucoanthocyanidin reductase; ANR: Anthocyanidin reductase; UFGT: UDP glucose flavonoid 3-Oglucosyltransferase; FAOMT: Flavonoid 3', 5'-methyltransferase (adapted from [25]). 

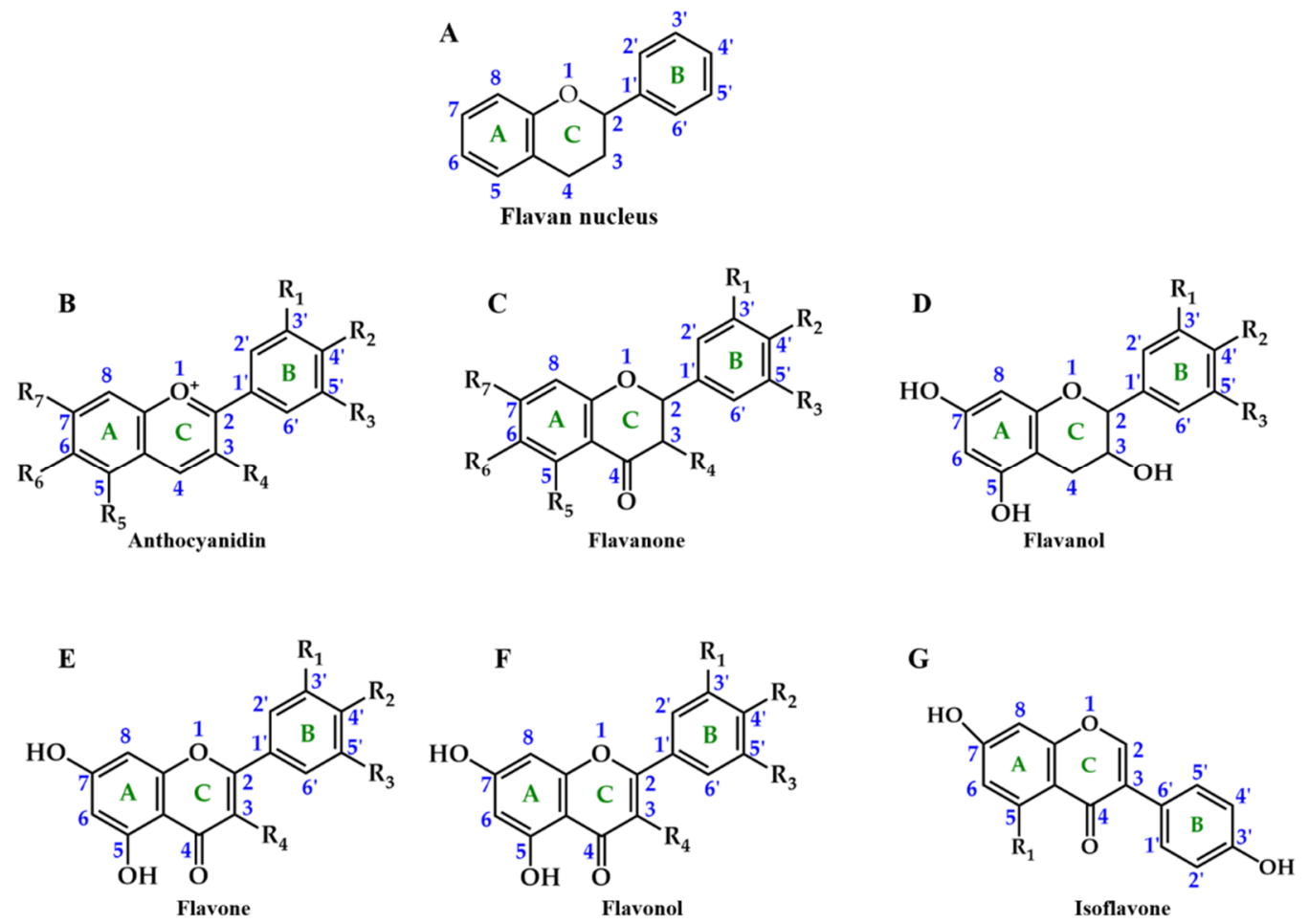

Figure 2. The basic structure of the flavonoids (A), which include anthocyanidins (e.g., cyanidin and pelargonidin) (B), flavanones (e.g., hesperidin and naringenin) (C), flavanols (e.g., catechin and epicatechin) (D), flavones (e.g., apigenin and luteolin) (E), flavonols (e.g., quercetin and kaempferol) (F), and isoflavones (e.g., daidzein and genistein) (G), differing in the level of oxidation and $\mathrm{C}$ ring saturation (adapted from [31]).

Focusing on anthocyanidins, their $\mathrm{B}$ ring is joined to the $\mathrm{C}$ ring through carbon 2 and the sugar residue of anthocyanins is typically found conjugated at carbon $3[32,33]$ (Figure 3). Furthermore, their capacity to create flavylium cations makes them distinguishable from other flavonoid subclasses [22]. To date, about 27 different structural anthocyanin aglycones and 1000 anthocyanins are known [34,35]. In foods, the most commonly found are sugar moieties of cyanidin (50\%), which is the most studied given their large distribution and number of hydroxyl groups, followed by pelargonidin, peonidin, and delphinidin $(12 \%)$, and finally by petunidin and malvidin glycosides (7\%) [8] (Figure 3). Together, they represent $90 \%$ of the total anthocyanins identified until now [36]. Their structure directly influences their biological potential, namely, the number of hydroxyl groups, the degree of glycosylation and acylation, the catechol residue on the $\mathrm{B}$ ring, and the oxonium ion on the C ring [37].

Therefore, the classification of anthocyanins is made according to (i) the number, position, and degree of methylation of the hydroxyl groups; (ii) the number and nature of the sugar moieties bonded to the aglycone; and (iii) the position of the aliphatic and/or aromatic carboxylate acids on the sugar molecule [38]. The stability of the anthocyanins is usually affected by the storage and processing conditions, temperature, and cooking, as well as by exposure to light and oxygen, the presence of enzymes, other phenolic compounds, metal ions, ascorbic acid, hydrogen peroxide $\left(\mathrm{H}_{2} \mathrm{O}_{2}\right)$, water, and/or sulphites [37]. 


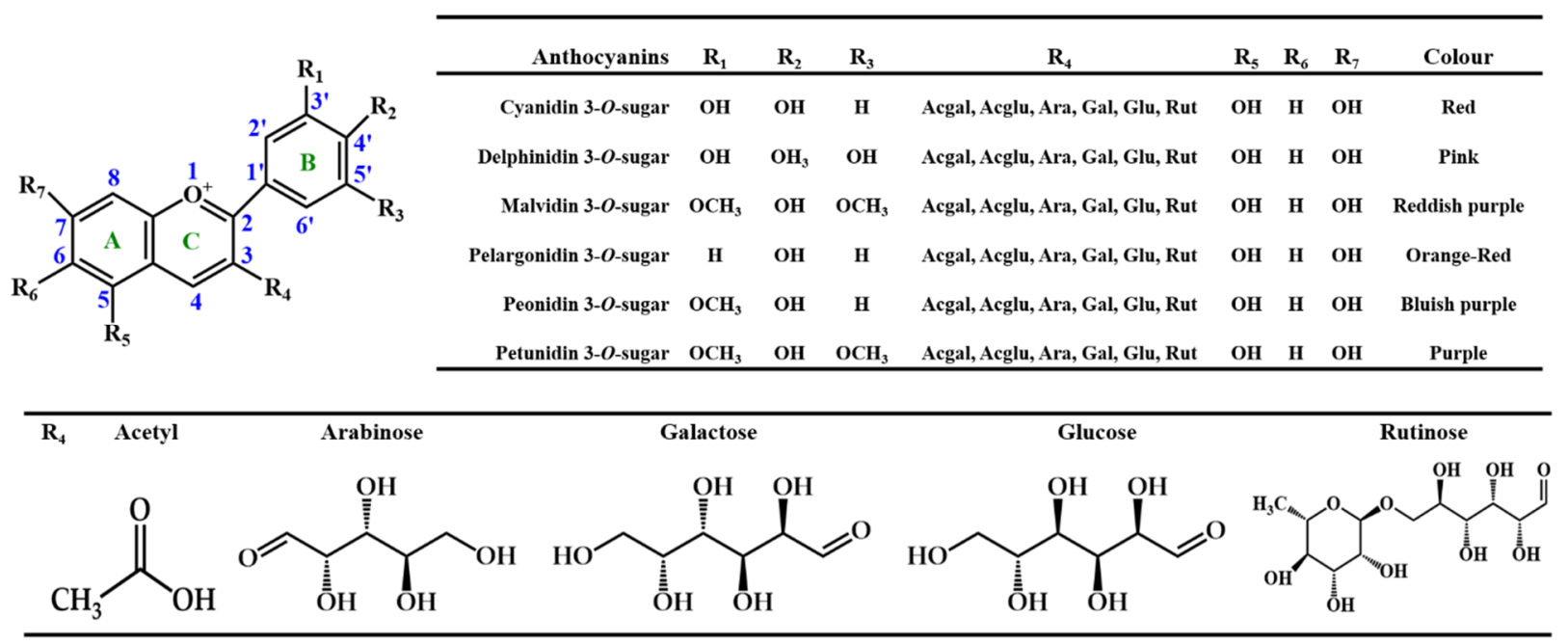

Figure 3. Representation of the main general chemical structure of anthocyanins. Acgal-acetylgalactose; Acgluacetylglucose; Ara—arabinose; Gal—galactose; Glu—glucose; Rut—rutinoside (adapted from [35,37]).

\section{Major Sources of Anthocyanins}

Anthocyanins are widely spread in nature and are considered mainly responsible for the vibrant red, blue, and purple colours exhibited by vegetables, fruits, and their derivatives [37,39]. Their levels differ markedly among different species, being largely influenced by plant genotypes, and less by agricultural practices, growing area, climatic conditions, seasonal variability, temperature and light exposure, ripening stage, harvest time, and the adopted methods for processing and storage [9,40].

The daily average intake of anthocyanins is estimated to vary from several milligrams to hundreds of milligrams, although its evaluation is inaccurate and depends on the diet, gender, existence (or not) of food intolerances in individuals, and their quantities in foods [41]. Their intake by humans is higher in countries with a Mediterranean diet, plentiful in reddish berries and other red and blue-coloured fruits and vegetables, and red wine [23,42]. In Europe, the ingestion ranges from $19.8 \mathrm{mg}$ per day (the Netherlands) to $64.9 \mathrm{mg}$ per day (Italy) in men and $18.4 \mathrm{mg}$ per day (Spain) to $44.1 \mathrm{mg}$ per day (Italy) in women [24]. In the United States of America, Australia, and Asian countries, the intake is about $12.5,24.2$, and $37 \mathrm{mg}$ per day per person, respectively $[23,42,43]$. Furthermore, and although it is not well established since they are non-essential nutrients, the recommended daily consumption of these coloured compounds has been evaluated, with China already recommending a daily intake of $50 \mathrm{mg}$ per day/person in order to reduce oxidative stress levels and consequently the risk of cancer, metabolic syndrome, diabetes, degenerative diseases, and other pathologies [44].

In a general way, the primary sources of anthocyanins are berries ( $43 \%$ in Europe and $39 \%$ in the USA), red wine (22\% in Europe and $18 \%$ in the USA), vegetables, and other fruits (19\% in Europe and 9\% in the USA) [45]. Table 1 presents the main sources of anthocyanins. A major amount of anthocyanins are found in berries, especially elderberries, chokeberries, blueberries, pomegranate, and açaí, presenting values superior to $282.5 \mathrm{mg}$ cyanidin 3glucoside equivalent per $100 \mathrm{~g}$ of fresh product $[46,47]$. Among the anthocyanins, cyanidin, malvidin, and delphinidin glycosides are the most found [47-50]. 
Table 1. Concentration of anthocyanins in fresh weight (FW) and dried weight (DW) in fruits, beverages, and vegetables.

\begin{tabular}{|c|c|c|c|c|}
\hline Source & $\begin{array}{l}\text { Maximum Anthocyanin Amount } \\
\text { in FW (mg C3G/100 g) }\end{array}$ & $\begin{array}{l}\text { Maximum Anthocyanin Amount } \\
\text { in DW (mg C } 3 \mathrm{G} / 100 \mathrm{~g})\end{array}$ & Dominant Anthocyanins & Reference \\
\hline \multicolumn{5}{|c|}{ Fruits } \\
\hline Açaí & $282.5-303.7$ & & $\begin{array}{c}\text { Cy 3,5-hexose pentose, Cy 3-O-glucoside, Cy 3-O-rutinoside, } \mathrm{Pg} 3 \text {-O-glucoside, } \\
\text { Pn 3-O-glucoside, Pn 3-O-rutinoside, Cy 3-(acetyl)hexose }\end{array}$ & [51] \\
\hline Acerola & $6.5-8.4$ & & Cy 3-rhamnoside, Pg 3-rhamnoside Cy, Pg & [51] \\
\hline Apple & $30.07-71.49$ * & & $\begin{array}{c}\text { Cy 3-galactoside, Cy 3-O-glucoside, Cy 3-arabinoside, Pn 3-galactoside, Cy } \\
\text { 7-arabinoside, Cy3-xyloside }\end{array}$ & {$[46,52]$} \\
\hline Blackberries & 70.3-201 & 909.3 & $\begin{array}{c}\text { Cy 3-O-glucoside, Cy 3-O-rutinoside, Cy 3-xyloside, Cy 3-malonylglucoside, } \\
\text { Cy 3-dioxalylglucoside }\end{array}$ & {$[53,54]$} \\
\hline Black currants & 218.93 & $32,300^{1}$ & Dp 3-O-glucoside, Dp 3-O-rutinoside, Cy 3-O-glucoside, Cy 3-O-rutinoside & {$[55,56]$} \\
\hline Blueberries & 406.90 & $1160^{1}$ & $\begin{array}{l}\text { Dp 3-O-galactoside, } \mathrm{Dp} \text { 3-O-glucoside, } \mathrm{Cy} \text {-3-O-galactoside, } \mathrm{Dp} \\
\text { 3-O-arabinoside, } \mathrm{Cy} \text {-3-glucoside, Pt-3-galactoside, } \mathrm{Cy} \text { 3-O-arabinoside, } \mathrm{Pt} \\
\text { 3-O-glucoside, Pn 3-O-arabinoside, Mv 3-O-galactoside, } \mathrm{Mv} \text { 3-O-glucoside }\end{array}$ & {$[55,57]$} \\
\hline Chokeberries & 357.20 & & Cy 3-O-galactoside, Cy 3-arabinoside, Cy 3-O-glucoside, Cy xyloside & {$[55,58]$} \\
\hline Cranberries & $40.7-207.3^{1}$ & & $\begin{array}{c}\text { Cy 3-O-galactoside Cy 3-O-glucoside, } \mathrm{Cy} \text { arabinoside, Pn galactoside, } \mathrm{Pn} \\
\text { 3-O-glucoside, Pn arabinoside }\end{array}$ & [59] \\
\hline Elderberries & 317.51 & $408.6-1066.6$ & Cy 3-O-glucoside, Сy 3-O-sambubioside & {$[55,60]$} \\
\hline Fig & $0.3-10.9$ & $4.6-83$ & $\begin{array}{l}\text { Cy 3-O-glucoside, Cy 3-O-rutinoside, Cy 3-sambubioside-5-glucoside, Cy } \\
\text { 3,5-diglucoside }\end{array}$ & {$[61,62]$} \\
\hline Grapes & $38.70-186.02^{1}$ & $135,960-533,630^{1}$ & $\mathrm{Cy}, \mathrm{Dp}, \mathrm{Mv}, \mathrm{Pn}, \mathrm{Pt}$ 3-O-glycosides; Mv, Pn, Pt 3-O-coumarylglucosides & {$[63,64]$} \\
\hline Haskaps & $449-697$ & 2273 & $\begin{array}{l}\text { Cy 3,5-di-glucoside; Cy 3-galactoside, Cy 3-O-glucoside, Cy 3-O-rutinoside, Pg } \\
\text { 3-O-glucoside; Pn 3-O-glucoside }\end{array}$ & {$[65,66]$} \\
\hline Nectarine & 0.22 & & Cy 3-O-glucoside, Cy 3-O-rutinoside & {$[46,67]$} \\
\hline Plums & $7.4-36.6^{1}$ & & $\begin{array}{c}\text { Cy 3-xyloside, Cy 3-O-glucoside, Cy 3-O-rutinoside, Pn 3-O-rutinoside, Pn } \\
\text { 3-O-glucoside, Cy 3-galactoside, Cy 3-(6"-acetoyl)glucoside }\end{array}$ & {$[46,68]$} \\
\hline Pomegranate & 1500-2000 & & $\begin{array}{l}\text { Dp 3,5-diglucoside, Cy 3-O-glucoside, Cy 3,5-diglucoside, Pg 3-O-glucoside, } \\
\text { Pg 3,5-diglucoside }\end{array}$ & {$[69,70]$} \\
\hline Peaches & $0.27-2.50$ & $0.28-15.34^{1}$ & Cy 3-O-rutinoside and glucoside & {$[71,72]$} \\
\hline
\end{tabular}


Table 1. Cont

\begin{tabular}{|c|c|c|c|c|}
\hline Source & $\begin{array}{l}\text { Maximum Anthocyanin Amount } \\
\text { in FW (mg C3G/100 g) }\end{array}$ & $\begin{array}{l}\text { Maximum Anthocyanin Amount } \\
\text { in DW (mg C } 3 \mathrm{G} / 100 \mathrm{~g})\end{array}$ & Dominant Anthocyanins & Reference \\
\hline Red cabbages & 109-185 & $1111-1780$ & $\begin{array}{c}\text { Cy 3-diglucoside-5-glucoside, Cy } \\
\text { 3-(sinapoyl)(sinapoyl)-diglucoside-5-glucoside, Cy } \\
\text { 3-( } \rho \text {-coumaroyl)-diglucoside-5-glucoside }\end{array}$ & {$[73,74]$} \\
\hline Red currants & 19.78 & $149.91^{1}$ & Cyanidin-3-O-sambusoside, Cy 3-O-glucoside, Cy 3-O-rutinoside & {$[55,75]$} \\
\hline Red pears & $1.2-12.0^{1}$ & & $\begin{array}{l}\text { Cy 3-O-galactoside, Cy 3-O-glucoside, Cy pentoside, Cy 3-O-arabinoside, Cy } \\
\text { 3-O-rutinoside }\end{array}$ & [76] \\
\hline Red raspberries & $23.17-68.0$ & $260.9-571.8$ & $\begin{array}{c}\text { Cy 3-O-sophoroside, Cy 3-O-(2"-O-glucosyl)rutinoside, } \mathrm{Cy} 3 \text {-O-glucoside, } \mathrm{Cy} \\
\text { 3-O-rutinoside, Cy 3-O-(2"-O-xylosyl)rutinoside, } \mathrm{Pg} 3-\mathrm{O} \text {-sophoroside, Pg } \\
\text { 3-O-glucoside, Cy 3,5-O-diglucoside }\end{array}$ & {$[53,55,77]$} \\
\hline Strawberries & $20-60^{1}$ & $31.9-315.2^{2}$ & $\begin{array}{c}\text { Pg 3-O-glucoside, Pg 3-O-glucoside, Cy 3-O-glucoside, } \mathrm{Cy} \text { 3-O-rutinoside, Pg } \\
\text { 3-O-glucoside, Pg 3-O-rutinoside, Pg 3-(malonoyl)glucoside, } \mathrm{Pg} \\
\text { 3-(6"-acetoyl)glucoside }\end{array}$ & {$[46,78,79]$} \\
\hline Sweet cherries & $2.06-462.77^{1}$ & $107.70-218.36^{1}$ & $\begin{array}{c}\text { Cy, Dp, Pg, Pn 3-O-rutinosides and glucosides, Cy 3-coumaroyl-diglucoside, } \\
\text { Cy 3-O-sambubioside, Cy 3-5-diglucoside, Cy 3-sophoroside Cy } \\
\text { 3-O-arabinoside Mv 3-O-glucoside-acetaldehyde }\end{array}$ & {$[40,80,81]$} \\
\hline Tart cherries & $65.06-82.40$ & 114.59 & $\begin{array}{c}\text { Cy, Cy 3-O-sophoroside, Cy 3-glucosylrutinoside, Cy 3-O-glucoside, Cy } \\
\text { 3-O-rutinoside, Pn 3-O-rutinoside }\end{array}$ & {$[55,83]$} \\
\hline Tomato & $7.1^{1}$ & $5.48-29.86^{3}$ & $\begin{array}{l}\text { Dp glycoside, } \mathrm{Dp} \text { rutinoside, } \mathrm{Dp} \rho \text {-coumaroyl-rutinoside } \mathrm{Mv} \text { glycoside, } \mathrm{Mv} \\
\text { rutinoside, } \mathrm{Mv} \rho \text {-coumaroyl-rutinoside-glycoside, } \mathrm{Pt} \text { rutinoside, } \mathrm{Pt} \\
\rho \text {-coumaroyl-rutinoside, } \mathrm{Pt} \rho \text {-coumaroyl-rutinoside-glycoside }\end{array}$ & {$[84,85]$} \\
\hline \multicolumn{5}{|c|}{ Vegetables } \\
\hline Black carrot & $22.45^{*}$ & $1.74-4.54^{1}$ & Cy 3-( $\rho$-coumaroyl)-diglucoside-5-glucoside & {$[47,86]$} \\
\hline Eggplant & 6.31 & $138^{4}$ & $\begin{array}{l}\text { Dp 3-( } \rho \text {-coumaroylrutinoside)-5-glucoside, Dp 3-O-glucoside, Dp } \\
\text { 3-glucosyl-rhamnoside, } \mathrm{Pt} \text {-3-O-rutinoside, Cy -3-O-rutinoside }\end{array}$ & {$[49,50]$} \\
\hline
\end{tabular}


Table 1. Cont.

\begin{tabular}{|c|c|c|c|c|}
\hline Source & $\begin{array}{l}\text { Maximum Anthocyanin Amount } \\
\text { in FW (mg C3G/100 g) }\end{array}$ & $\begin{array}{l}\text { Maximum Anthocyanin Amount } \\
\text { in DW (mg C3G/100 g) }\end{array}$ & Dominant Anthocyanins & Reference \\
\hline $\begin{array}{l}\text { Purple sweet } \\
\text { potato }\end{array}$ & $42.37 *$ & & $\begin{array}{c}\text { Pn 3-O-sophoroside-5-O-glucoside, Pn 3-O-glucoside, Cy } \\
\text { 3- } \rho \text {-hydroxybenzoylsophoroside-5-glucoside, Pn } \\
\text { 3- } \rho \text {-hydroxybenzoylsophoroside-5-glucoside, Cy } \\
\text { 3-caffeoylsophoroside-5-glucoside, Pn 3-caffeoylsophoroside-5-glucoside, } \\
\text { Cyanidin-3-caffeoyl- } \rho \text {-hydroxybenzoylsophoroside-5-glucoside, Pn } \\
\text { 3-dicaffeoylsophoroside-5-glucoside, Pn } \\
\text { 3-caffeoyl- } \rho \text {-hydroxybenzoylsophoroside-5-glucoside, Pn } \\
\text { 3-caffeoy-feruloylsophoroside-5-glucosie }\end{array}$ & [47] \\
\hline Red Chicory & $39.20 *$ & & Сy 3-O-glucoside, Сy 3-O-(6"-malonyl-glucoside) & [47] \\
\hline Red onion & 29.99 & & $\begin{array}{c}\text { Cy 3-O-glucoside, Cy 3-O-laminaribioside, Cy 3-(6"-malonyl-glucoside), Cy } \\
\text { 3-(6"-malonyl- laminaribioside), Cy 3-xylosylglucosylgalactoside, Dp } \\
\text { 3,5-diglycosides }\end{array}$ & {$[47,87]$} \\
\hline \multicolumn{5}{|c|}{ Beverages } \\
\hline Blackberry juice & $12.3-107$ & & $\begin{array}{l}\text { Cy 3-O-glycoside, Cy 3-O-rutinoside, Cy 3-xyloside, Cy malonylglucoside, Cy } \\
\text { dioxalylglucoside }\end{array}$ & {$[54]$} \\
\hline Red wine & $32.71-87.17^{1}$ & & $\begin{array}{c}\text { Cy, Dp, Mv, Pn, Pt 3-O-glycosides, Pn 3-O-acetylglucoside, } \mathrm{Mv} \\
\text { 3-O-acetylglucoside, Mv 3-O-coumarylglucoside, Pn 3-O- } \rho \text {-coumarylglucoside; }\end{array}$ & {$[48,89]$} \\
\hline Tart cherry juice & & 72.2 & $\begin{array}{c}\text { Cy 3-sophoroside, Cy 3-glucosylrutinoside, Cy 3-O-glucoside, Cy } \\
\text { 3-O-rutinoside, Cy, Pg, Pn 3-O-glucoside }\end{array}$ & [90] \\
\hline
\end{tabular}

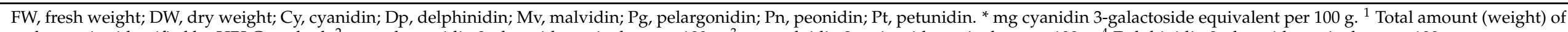
anthocyanins identified by HPLC method. ${ }^{2}$ mg pelargonidin 3-glucoside equivalent per $100 \mathrm{~g} .{ }^{3} \mathrm{mg}$ malvidin 3-rutinoside equivalent per $100 \mathrm{~g} .{ }^{4}$ Delphinidin 3 -glucoside equivalent per $100 \mathrm{~g}$. 


\section{Anthocyanins' Bioavailability and Metabolism}

Understanding the bioavailability of phenolics is crucial since, after consumption, their constituents undergo many modifications throughout the digestive tract (digestion, absorption, metabolization, and elimination), which have a great impact on their nutritional value and health-promoting properties [28,31].

Nowadays, it is established that the bioavailability of phenolics differs significantly between them, and therefore, the most abundant polyphenols in our dietary habits are not necessarily those that show the highest concentrations of active metabolites in organs and tissues [35]. Indeed, their bioavailability is highly dependent on the chemical structure of the phenolics, i.e., their molecular size, pattern of glycosylation and/or acylation (where acylation increases anthocyanin stability but declines their absorption), degree of polymerization, and conjugations and/or combinations with other compounds [36,91]. Furthermore, it is also influenced by the $\mathrm{pH}$ values observed along the gastrointestinal tract, facilitation of the compounds to cross membranes, digestibility, solubility, and absorption actions carried out by digestive enzymes, biliary acids, gut microbiota, and enterocytes. The food matrix maturity degree and cooking also influence the availability rates [35]. Although the thermal processing reduces anthocyanins' stability, at the same time, it damages the anthocyanin cell walls, increasing their body absorption [28].

It is also important to take into account that the bioavailability also varies among individuals -inter-individual variability — due to intrinsic aspects (e.g., age, sex, physiological and/or pathological states, and genetic factors), which induce marked differences regarding enzymes and microbiota activity [43].

Unlike other phenolics, anthocyanins are quickly metabolized and eliminated, and even in high amounts, they rarely reach concentration values considered active. In fact, the intake of 10 and $720 \mathrm{mg}$ of anthocyanins only results in maximal plasma concentrations of 1.4 and 200 nanomolar, respectively, achieved between $30 \mathrm{~min}$ and $2 \mathrm{~h}$ [92-94].

Table 2 summarizes the principal human trials focused on the pharmacokinetic profile of anthocyanins observed after their ingestion in common foods and beverages. In a general way, less than $1.8 \%$ of consumed anthocyanins is normally absorbed. However, this percentage can decrease if they are ingested alone, with or after other compounds; i.e., if anthocyanins are consumed alone or after overnight fasting, their digestion happens in 1 hour [93,95], whereas if they are ingested accompanied by other foods and beverages, ingested with high-fat meals, or after a meal, it occurs only after 1.5 or $4 \mathrm{~h}$, respectively [96]. They disappear from the blood circulatory system in less than $6 \mathrm{~h}$ [57].

Additionally, and considering that substitutions influence anthocyanin absorption, nowadays, it is well-described that pelargonidin derivatives are more readily absorbed than anthocyanins with more substituents on their B ring, such as peonidin-, delphinidin-, and cyanidin-based anthocyanins [46]. Furthermore, and comparing the sugar moieties, it was already verified that malvidin 3-O-arabinoside presents higher absorption rates than malvidin 3-O-glucoside [103].

Despite their low absorption and rapid metabolism, the regular consumption of anthocyanins is considered safe, and together with physical activity, it is encouraged as both can reduce the occurrence of several pathologies related to oxidative stress [36]. As far as we know, until now, no adverse effects regarding anthocyanin consumption have been reported. In fact, and focusing on human studies, most people who consumed $160 \mathrm{mg}$ of anthocyanins twice a day for 2 months tolerated the extract; only $4 \%$ of the participants revealed side effects, namely at the gastrointestinal level and eczema [104,105].

Therefore, after being consumed, anthocyanins are metabolized in the mouth, where the action of oral microbiota removes the glycosidic groups and transforms them into their corresponding chalcones [106]. 
Table 2. Human studies considering the pharmacokinetic parameters of anthocyanins, after ingestion of common foods and beverages rich in this type of compound.

\begin{tabular}{|c|c|c|c|c|c|c|c|}
\hline Intake & $n^{(\mathrm{a})}$ & Total Anthocyanins Intake & $\mathrm{C}_{\max }(\mathrm{b})$ & $t_{\max (h)}(c)$ & $\operatorname{AUC}^{(\mathrm{d})}$ & Urinary Excretion (\%) & Reference \\
\hline \multicolumn{8}{|c|}{ Foods } \\
\hline Blueberries (100 g) & 5 & $1200 \mathrm{mg}$ & $13.1 \mathrm{ng} / \mathrm{mL}$ & 4 & & & {$[57]$} \\
\hline Red raspberries (300 g) & 9 & $292 \mu \mathrm{Mol}$ & $0.1-180 \mathrm{nmol} / \mathrm{L}$ & $1-1.5$ & & $0.007 \%(1-1.5 \mathrm{~h})$ & [77] \\
\hline \multicolumn{8}{|c|}{ Beverages } \\
\hline Red wine (300 mL) & 6 & $218 \mathrm{mg}$ & & 6 & & $1.5-5.1 \%(12 \mathrm{~h})$ & [89] \\
\hline \multirow{6}{*}{ Red grape juice (400 mL) } & \multirow{6}{*}{9} & Сy 3-O-glucoside & $0.42 \mathrm{ng} / \mathrm{mL}$ & 0.5 & $0.60 \mathrm{ng} \times \mathrm{h} / \mathrm{mL}(3 \mathrm{~h})$ & $0.09 \%(7 \mathrm{~h})$ & \multirow{6}{*}{ [97] } \\
\hline & & Dp 3-O-glucoside & $6.12 \mathrm{ng} / \mathrm{mL}$ & 0.5 & $11.9 \mathrm{ng} \times \mathrm{h} / \mathrm{mL}(3 \mathrm{~h})$ & $0.20 \%(7 \mathrm{~h})$ & \\
\hline & & Mv 3-O-glucoside & $48.8 \mathrm{ng} / \mathrm{mL}$ & 0.5 & $71.7 \mathrm{ng} \times \mathrm{h} / \mathrm{mL}(3 \mathrm{~h})$ & $0.18 \%(7 \mathrm{~h})$ & \\
\hline & & Pn 3-O-glucoside & $27.3 \mathrm{ng} / \mathrm{mL}$ & 0.5 & $49.7 \mathrm{ng} \times \mathrm{h} / \mathrm{mL}(3 \mathrm{~h})$ & $0.29 \%(7 \mathrm{~h})$ & \\
\hline & & Pt 3-O-glucoside & $16.1 \mathrm{ng} / \mathrm{mL}$ & 0.5 & $31.5 \mathrm{ng} \times \mathrm{h} / \mathrm{mL}(3 \mathrm{~h})$ & $0.32 \%(7 \mathrm{~h})$ & \\
\hline & & $\Sigma=283.5 \mathrm{mg}$ & $100.1 \mathrm{ng} / \mathrm{mL}$ & 0.5 & $168.4 \mathrm{ng} \times \mathrm{h} / \mathrm{mL}$ & & \\
\hline \multirow{3}{*}{ Black currant juice $(150 \mathrm{~mL})$} & \multirow{3}{*}{8} & Cy 3-O-glucoside: $0.165 \mathrm{mg}$ & $5.0 \mathrm{nmol} / \mathrm{L}$ & 1.34 & $11.0-19.6 \mathrm{ng} \times \mathrm{h} / \mathrm{mL}(4 \mathrm{~h})$ & $0.060 \%(8 \mathrm{~h})$ & \multirow{3}{*}{ [96] } \\
\hline & & Dp 3-O-glucoside: $0.488 \mathrm{mg}$ & $22.7 \mathrm{nmol} / \mathrm{L}$ & 4.19 & $11.0-16.3 \mathrm{ng} \times \mathrm{h} / \mathrm{mL}(4 \mathrm{~h})$ & $0.066(8 \mathrm{~h})$ & \\
\hline & & Dp 3-O-rutinoside: $1.68 \mathrm{mg}$ & $73.4 \mathrm{nmol} / \mathrm{L}$ & 3.18 & $16.3-24.9 \mathrm{ng} \times \mathrm{h} / \mathrm{mL}(4 \mathrm{~h})$ & $0.11 \%(8 \mathrm{~h})$ & \\
\hline $\begin{array}{c}\text { Açaí Juice }(7 \mathrm{~mL} / \mathrm{kg} \text { of body } \\
\text { weight })\end{array}$ & 12 & $165.9 \mathrm{mg} / \mathrm{L}$ & $1138.51 \mathrm{ng} / \mathrm{L}$ & 2 & $3314.04 \mathrm{ng} \times \mathrm{h} / \mathrm{L}(12 \mathrm{~h})$ & & [11] \\
\hline \multirow{8}{*}{ Cranberry Juice (480 mL) } & \multirow{8}{*}{15} & Cy 3-O-galactoside (18.7 mg) & $1.38 \mathrm{nmol} / \mathrm{L}$ & 1.27 & $3.91 \mathrm{nmol} \times \mathrm{h} / \mathrm{L}(4 \mathrm{~h})$ & $0.007 \%(4 \mathrm{~h})$ & \multirow{8}{*}{ [98] } \\
\hline & & Cy 3-O-glucoside (1.58 mg) & $0.93 \mathrm{nmol} / \mathrm{L}$ & 1.13 & $1.99 \mathrm{nmol} \times \mathrm{h} / \mathrm{L}(4 \mathrm{~h})$ & $0.007 \%(4 \mathrm{~h})$ & \\
\hline & & Cy 3-O-arabinoside (16.47 mg) & $3.61 \mathrm{nmol} / \mathrm{L}$ & 1.47 & $9.16 \mathrm{nmol} \times \mathrm{h} / \mathrm{L}(4 \mathrm{~h})$ & $0.010 \%(4 \mathrm{~h})$ & \\
\hline & & Mv 3-O-glucoside & $0.56 \mathrm{nmol} / \mathrm{L}$ & 0.93 & $1.25 \mathrm{nmol} \times \mathrm{h} / \mathrm{L}(4 \mathrm{~h})$ & & \\
\hline & & Pn 3-O-galactoside (30.83 mg) & $4.64 \mathrm{nmol} / \mathrm{L}$ & 1.47 & $12.00 \mathrm{nmol} \times \mathrm{h} / \mathrm{L}(4 \mathrm{~h})$ & $0.015 \%(4 \mathrm{~h})$ & \\
\hline & & Pn 3-O-glucoside (5.85 mg) & $0.71 \mathrm{nmol} / \mathrm{L}$ & 1.40 & $1.85 \mathrm{nmol} \times \mathrm{h} / \mathrm{L}(4 \mathrm{~h})$ & $0.029 \%(4 \mathrm{~h})$ & \\
\hline & & Pn 3-O-arabinose (21.03 mg) & $1.78 \mathrm{nmol} / \mathrm{L}$ & 1.27 & $4.13 \mathrm{nmol} \times \mathrm{h} / \mathrm{L}(4 \mathrm{~h})$ & $0.010 \%(4 \mathrm{~h})$ & \\
\hline & & $\Sigma=94.47 \mathrm{mg}$ & & & & & \\
\hline
\end{tabular}


Table 2. Cont.

\begin{tabular}{|c|c|c|c|c|c|c|c|}
\hline Intake & $n^{\text {(a) }}$ & Total Anthocyanins Intake & $C_{\max }(b)$ & $t_{\max (h)}(c)$ & $\mathrm{AUC}^{(\mathrm{d})}$ & Urinary Excretion (\%) & Reference \\
\hline Tart cherry juice (60 mL) & 12 & $62.47 \mathrm{mg} / \mathrm{L}$ & $2.75 \mu \mathrm{g} \times \mathrm{h} / \mathrm{mL}$ & 1 & $106.4 \mu \mathrm{g} \times \mathrm{h} / \mathrm{mL}$ & & [99] \\
\hline \multirow{9}{*}{ Grape/blueberry juice $(330 \mathrm{~mL})$} & \multirow{9}{*}{10} & 3,4-dihydroxybenzoic acid & $7.6 \mathrm{nmol} / \mathrm{L}$ & 1 & $568 \mathrm{nmol} \times \mathrm{min} / \mathrm{L}$ & & \multirow{9}{*}{ [100] } \\
\hline & & Cy 3-O-glucoside & $0.10 \mathrm{nmol} / \mathrm{L}$ & 1 & $6 \mathrm{nmol} \times \mathrm{min} / \mathrm{L}$ & & \\
\hline & & Dp 3-O-glucoside & $0.18 \mathrm{nmol} / \mathrm{L}$ & 1.1 & $10 \mathrm{nmol} \times \mathrm{min} / \mathrm{L}$ & & \\
\hline & & Mv 3-O-glucoside & $1.5 \mathrm{nmol} / \mathrm{L}$ & 1.1 & $103 \mathrm{nmol} \times \mathrm{min} / \mathrm{L}$ & & \\
\hline & & Mv 3-O-glucuronide & $1.1 \mathrm{nmol} / \mathrm{L}$ & 2 & $114 \mathrm{nmol} \times \mathrm{min} / \mathrm{L}$ & & \\
\hline & & Pn 3-O-glucuronide & $1.1 \mathrm{nmol} / \mathrm{L}$ & 1.8 & $114 \mathrm{nmol} \times \mathrm{min} / \mathrm{L}$ & & \\
\hline & & Pn 3-O-glucoside & $1.7 \mathrm{nmol} / \mathrm{L}$ & 1 & $52 \mathrm{nmol} \times \mathrm{min} / \mathrm{L}$ & & \\
\hline & & Pt 3-O-glucoside & $0.8 \mathrm{nmol} / \mathrm{L}$ & 1 & $12 \mathrm{nmol} \times \min / \mathrm{L}$ & & \\
\hline & & $\Sigma=841 \mathrm{mg} / \mathrm{L}$ & $1.21 \mathrm{nmol} / \mathrm{L}$ & & & & \\
\hline Orange juice & 18 & $53.09 \mathrm{mg} / \mathrm{L}$ & $0.63 \mathrm{nmol} / \mathrm{L}$ & 0.96 & $8.99 \mathrm{nmol} \times \mathrm{h} / \mathrm{L}(8 \mathrm{~h})$ & $43-53 \%(2 \mathrm{~h})$ & {$[101]$} \\
\hline $\begin{array}{c}\text { Chokeberry juice }(0.8 \mathrm{mg} / \mathrm{kg} \text { of } \\
\text { body weight) }\end{array}$ & 13 & & $32.7 \mathrm{nmol} / \mathrm{L}$ & 1.3 & $109.4 \mathrm{nmol} \times \mathrm{h} / \mathrm{L}(1 \mathrm{~h})$ & $0.25(24 \mathrm{~h})$ & [102] \\
\hline \multirow{4}{*}{ Strawberry juice (34.7 mg) } & \multirow{4}{*}{14} & Pg glucuronide & $38.0 \mathrm{nmol} / \mathrm{L}$ & 1.7 & $123.8 \mathrm{nmol} \times \mathrm{h} / \mathrm{L}(10 \mathrm{~h})$ & & \multirow{4}{*}{ [95] } \\
\hline & & Pg-3-O-glucoside: $58.8 \mu \mathrm{Mol}$ & $5.2 \mathrm{nmol} / \mathrm{L}$ & 1.3 & $15.0 \mathrm{nmol} \times \mathrm{h} / \mathrm{L}(10 \mathrm{~h})$ & & \\
\hline & & Pg 3-O-rutinoside: $9.7 \mu \mathrm{Mol}$ & $0.4 \mathrm{nmol} / \mathrm{L}$ & 1.9 & $1.4 \mathrm{nmol} \times \mathrm{h} / \mathrm{L}(10 \mathrm{~h})$ & & \\
\hline & & $\Sigma=76.6 \mu \mathrm{Mol}$ & & & & & \\
\hline
\end{tabular}

${ }^{(a)}$ Number of participants. ${ }^{(b)}$ Maximum concentration in plasma. ${ }^{(c)}$ Time to reach $C_{\max }$ in plasma. ${ }^{(d)}$ Area under the curve, which describes the exposure of a compound over a set period of time. 
After that, they pass along the gastrointestinal tract, starting in the stomach, where they do not suffer considerable changes, despite the acidic $\mathrm{pH}$, and can be absorbed by bilitranslocase, becoming available for absorption (bioaccessibility) [106,107], or reach intestinal epithelial cells [108]. In fact, the literature suggests that it is possible that the gastric and intestinal bioavailability of anthocyanins are mainly done with the 3-monoglucosides, 3-monoglucoside acylated, and 3,5-diglucosides forms [106,107,109].

Therefore, anthocyanins can go through the portal vein to the liver and can be directed to the systemic circulation to be taken up by the target organs and tissues, or, if they are not absorbed, be discarded through urine and faeces (Figure 4) [41,110]. It is important to note that in intestines, liver, and kidneys, anthocyanins are metabolized by enzymes of phase I and phase II, being conjugated with additional hydroxyl, methyl, sulfuric, or glycoside groups in order to increase their availability [33,36,111].

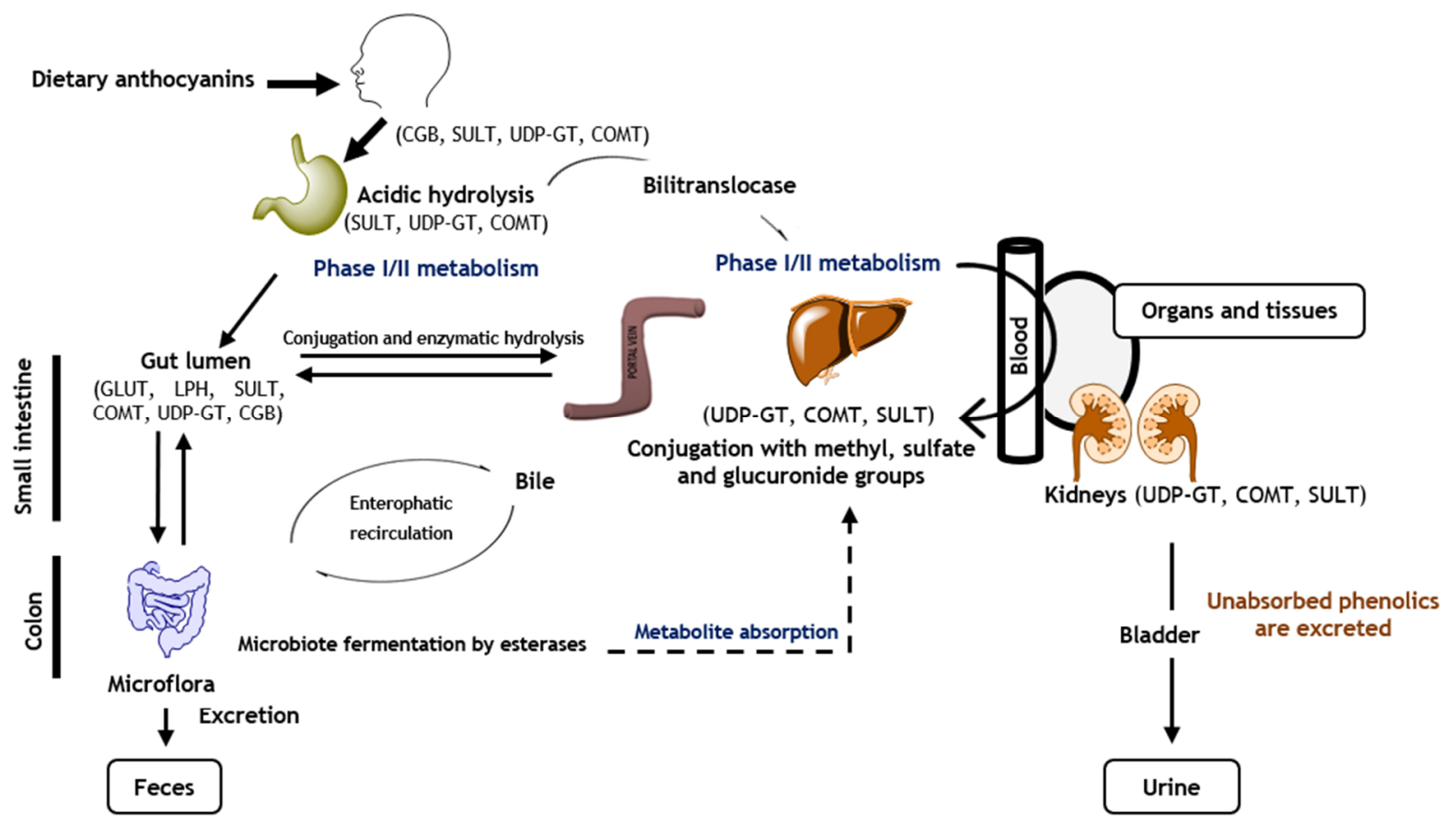

Figure 4. Anthocyanin absorption, distribution, metabolism, and excretion. CGB—cytosolic $\beta$-glucosidase; SULTsulfotransferase; UDP-GT_glucuronosyltransferase; COMT—catechol-O-methyl transferase; GLUT-glucose transporters; LPH-lactase-phlorizin hydrolase.

In general, both native anthocyanidins and their conjugated forms are found in plasma and urine; nevertheless, the intact ones are more rapidly absorbed in the stomach (20-25\%) and detected in plasma a few minutes after their ingestion [112]. This evidence is supported by previous studies based on the oral ingestion of red fruits, which revealed that anthocyanins are not metabolized into their aglycones, being directly absorbed and appearing in plasma $30 \mathrm{~min}$ after their consumption [92]. Their glycosylated forms are excreted in urine $[8,93]$.

Notwithstanding, the major absorption rate is observed in the gut [33]. Therefore, in the gut, the lactase-phlorizin hydrolase (LPH) and $\beta$-glucosidase enzymes release the aglycone of the coloured compounds, increasing their hydrophobic character, thus facilitating their entrance by passive diffusion in epithelial cells [113]. Glycosides and acylated anthocyanins can also be absorbed by the small intestine due to the action of glucose transporters 1 and 3 (GLUT 1 and 3) [91,109,111,114]; however, the absorption of the acylated ones is four times lower than that of non-acylated anthocyanins [33]. Particularly, molecular docking studies revealed that smaller molecules interact with GLUT 1 and 3 by their glucose residue and AC rings, while larger compounds penetrate in both transporters by their C5 glucose, as well as B and coumaroyl rings [91,109]. 
Unabsorbed anthocyanins reach the colon and are hydrolysated within $20 \mathrm{~min}-2$ $\mathrm{h}$ by colonic bacteria (e.g., $\alpha$-galactosidase, $\beta$-D-glucuronidase, $\beta$-D-glucosidase, and $\alpha$ rhamnosidase), which break down the glycosidic bonds and catalyse them into smaller phenolic compounds (e.g., benzaldehydes or hydroxytyrosol) or simple phenolic acids, such as $\rho$-hydroxybenzoic, homovanillic, phenylpropionic, protocatechuic, syringic, and vanillic acids, to simplify their absorption by colonic mucosa and consequently increase their availability [115]. This extensive metabolization is tremendously interesting and shows that the availability of anthocyanins is probably higher than we thought, and the reason why anthocyanins can be found in urine in amounts below $0.1 \%[91,116]$. Indeed, a recent study indicates the intake of $300 \mathrm{~g}$ of red raspberries results in the identification of 18 different anthocyanin-derived metabolites [77]. Basically, delphinidin-based anthocyanins are transformed into 2,4,6-trihydroxybenzaldehyde, gallic, and syringic acids, while syringic, 4-hydroxybenzoic, and vanillic acids are the primary metabolites of malvidin, pelargonidin, and peonidin glucosides, respectively [111,117]. Cyanidin glycosides can produce around 35 metabolites, 31 being found in urine samples, 28 in faeces, and 17 in the circulatory system, where the main ones are 2,4,6-trihydroxybenzaldehyde, $\rho$-coumaric, protocatechuic and vanillic acids, and phenolic conjugates (e.g., hippuric, phenylacetic, and phenylpropenoic acids) [77,118].

Additionally, the cleavage of glycosidic bonds also enhances the beneficial effects exhibited by anthocyanins [33]. In fact, this modulation on colon microflora leads to the formation of short-chain fatty acids that together with phenolic acids induce a decrease in $\mathrm{pH}$ values, creating favourable conditions for the proliferation of probiotic bacteria, such as Actinobacteria, Bifidobacteria, and Lactobacilli $[33,111]$. These bacteria exert positive effects in the control of gastrointestinal and digestive disorders, allergies, eczema, and improvements in delicate cases of cardiac and mental illness [10,119].

\section{Anthocyanin Encapsulation}

Knowing that the incorporation of phenolic compounds into foods and pharmaceutical products is a challenge, due to their instability and susceptibility to degradation, during processing and storage, various delivery systems have been developed [4]. Among them, encapsulation is a good strategy. This technology allows entrapping an active agent, liquid, gas, or solid within a matrix or a polymeric wall in micro or nanoparticles, to protect the active compound from environmental conditions, undesirable interactions, and to control their transportation, release, and handling. The most common polymers used are carbohydrates (e.g., cellulose derivatives and maltodextrins), natural gums (e.g., alginates and gum arabic), lipids (e.g., emulsifiers and waxes), and/or proteins (e.g., dairy proteins, gelatine, and soy proteins) [33]. Additionally, their combination with other wall materials and some modifiers, such as antioxidants, chelate agents, and surfactants, can also increase the encapsulation benefits [4]. In a general way, the process of encapsulation is based on the formation of the wall around the compound of interest, ensuring that unwanted materials are kept outside, and preventing undesired leaks to happen. It is important to take into account, along with its cost, the particle size and physicochemical properties of the core and the origin of wall constituents, to favour capsule stability. To that end, several methods have been developed, and the best-known ones for anthocyanin encapsulation are emulsification, ionotropic gelation, thermal gelation, and spray-drying. This last one is the most applied technique (80-90\% of encapsulated formulations are spray-dried) due to their cost and easy procedure [4]. Maltodextrins are the most used coating material given their ability to maintain anthocyanin stability [120].

Therefore, and in order to enhance their bioefficacy and stability, and thus prevent their rapid degradation, anthocyanins are mainly encapsulated with liposomes, nanocomplexes of alginate and chitosan, and gel emersions [34]. In fact, several studies already showed that anthocyanin nano-formulations, along with chemical modifications, favour their absorption and metabolization, and consequently increase their biological action [33]. Mueller et al. [112] conducted a human study and reported that the encapsulation of $2.4 \mathrm{~g}$ of 
blueberry anthocyanins with whey protein does not contribute to anthocyanin stabilization during intestinal passage given their ability to prolong their passage through the stomach, whereas the encapsulation with citrus pectin improves anthocyanin bioavailability and intestinal accessibility, thus increasing their concentrations in the bloodstream.

Furthermore, bioengineering-based, targeted drug delivery approaches using biodegradable PLGA@PEG nanoparticles revealed more notable results in both in vivo and in vitro Alzheimer's disease models than anthocyanins alone, namely, lower levels of oxidative stress and neuroinflammatory hallmarks [121,122]. Furthermore, $50 \mathrm{mg} / \mathrm{mL}$ of blueberry anthocyanins encapsulated in liposomal micelles also revealed higher anticancer activity than non-encapsulated anthocyanins on K562 human erythroleukemic cancer cells [123].

\section{Putative Health Benefits}

The low ingestion of fruits and vegetables causes around 1.7 million deaths worldwide, being related to $14 \%$ of gastrointestinal malignancies, $9 \%$ of stroke, and $11 \%$ of coronary artery disorders [36]. Therefore, it is undeniable the role of anthocyanins in promoting human health and welfare [105]. Several in vitro scavenging assays, animal and human cell lines studies, animal models, and human clinical trials already indicated that the consumption of foods, beverages, and supplements rich in anthocyanins brings numerous health benefits. In fact, this is due to the easy capacity of the anthocyanins to eliminate and/or neutralize free radicals and reactive species, chelate metals, control signalling pathways, diminish pro-inflammatory markers, and, thus, reduce the risk of cardiovascular pathologies, cancer, and neurodegeneration. Additionally, they also contribute to control weight and improve vision. The general health benefits resulting from the consumption of anthocyanins are shown in Figure 5.

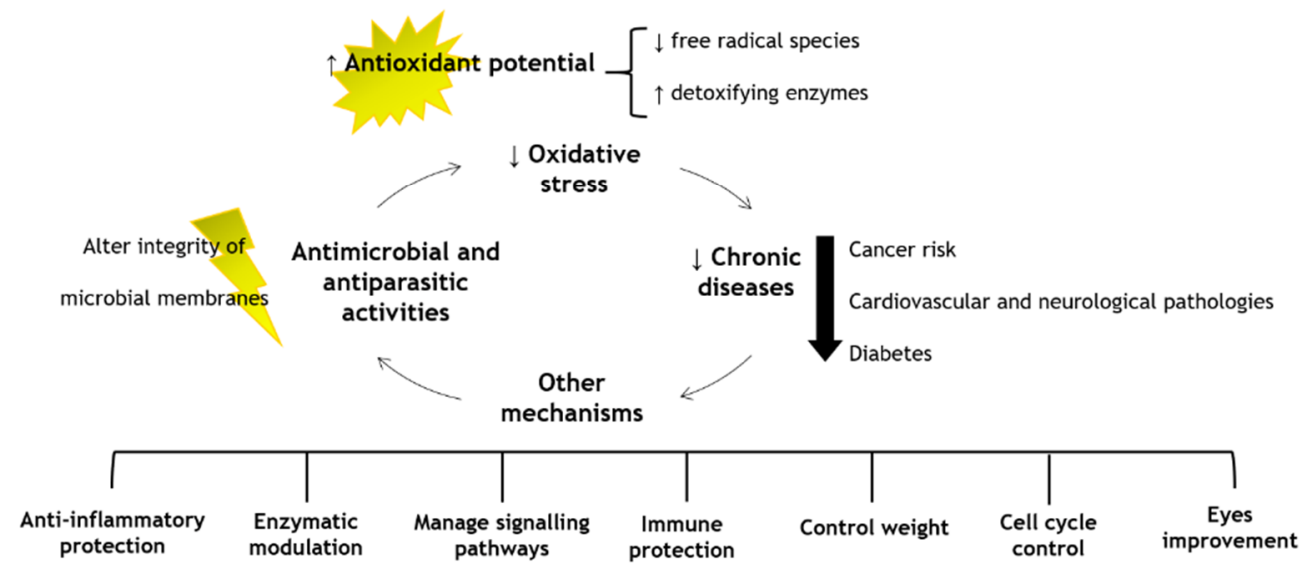

Figure 5. Health benefits of anthocyanins.

\subsection{Antimicrobial Effects and Anti-Parasitic Activity}

In order to attenuate the emerging resistance of microorganisms to antibiotics over time, natural products have gained much attention since they are rich in many metabolites with antimicrobial, antifungal, and anti-parasitic effects. In fact, these activities are part of the plants' defense mechanism against pathogens and infections during their development and growth. Among these phytochemicals, anthocyanins already showed capacity to reduce the replication and growth of some Gram-negative and Gram-positive bacteria and parasites [124,125]. 
Anthocyanins already revealed an ability to stop the replication of two common foodborne pathogens, Escherichia coli and Salmonella, exhibiting minimum inhibitory concentration (MIC) values varying from 10 to $400 \mathrm{mg} / \mathrm{mL}$, and also to reduce the growth of Desulfovibrio spp. and Enterococcus pathogenic bacteria by increasing the abundance of probiotics, such as Akkermansia and Bifidobacteria [124]. These results are in accordance with those reported by Sun et al. [125], who also revealed that anthocyanin-rich extracts from blueberries can also destroy the cell membrane of Listeria monocytogenes, Staphylococcus aureus, and Vibrio parahaemolyticus, displaying MIC scores of $0.27,0.21$, and $0.030 \mathrm{mg} / \mathrm{mL}$, respectively, after $24 \mathrm{~h}$ of exposure. Furthermore, it has also been reported that $100 \mu \mathrm{M}$ cyanidin 3-O-glucoside can also inhibit the expression and secretion of Helicobacter pylori toxins by suppressing the SecA transcription pathway, thereby making the proteins' exportation difficult [126]. Even though delphinidin 3-O-rutinoside and cyanidin 3-O-rutinoside at $1 \%$ did not reveal any inhibitory effect, enriched fractions of berries at concentrations ranging from 0.1 to $1 \%$ showed capacity to inhibit the yeasts Saccharomyces cerevisiae and Rhodotorula rubra, and the bacteria Bacillus cereus, Salmonella typhimurium, and Lactococcus lactis cocci growth [127]. Mulberry anthocyanins also showed potential to interfere with the development of Pseudomonas aeruginosa, a microorganism associated with biofilm-mediated infections, exhibiting an MIC value of $2 \mathrm{mg} / \mathrm{mL}$ [128]. Similar results were observed concerning the anti-microbial effects of blackcurrants and cherries on suppressing the growth of S. aureus, E. coli, and P. aeruginosa bacteria [129]. More recently, Silva et al. reported that anthocyanin-rich blueberry extracts at concentrations superior to $1 \mathrm{mg} / \mathrm{mL}$ can also inhibit virulence factors, namely, the formation of biofilms and adhesion of Acinetobacter baumannii and Proteus mirabilis pathogenic microorganisms over $24 \mathrm{~h}$ of treatment [130].

A dose of $0.225 \mu \mathrm{g} / \mathrm{mL}$ of cornelian cherry fruits showed potential to stimulate murine immune response during Trichinella spiralis infection, a causative agent of human trichinellosis, by enhancing the $\mathrm{CD}^{+}, \mathrm{CD}^{+}$, and erythrocytes cells, promoting platelet aggregation and decreasing $\mathrm{CD}^{+}$splenocyte cells when compared to T. spiralis-infected mice that did not receive the extract [131]. Besides, it has already been reported that Kenyan purple tea anthocyanins $(200 \mathrm{mg} / \mathrm{kg})$ can ameliorate post-treatment reactive encephalopathy associated with cerebral human trypanosomiasis, caused by Trypanosoma brucei parasites in a murine model, after 21 days of treatment, by delaying the establishment of the trypanosomes and increasing the glutathione and aconitase- 1 levels in the brain compared to the untreated group [132]. Additionally, anthocyanins isolated from black soybean already revealed the potential to control chronic bacterial prostatitis, an infection from the lower genitourinary tract, in rat models, over 4 weeks of treatment at doses of $50 \mathrm{mg} / \mathrm{kg}$ administrated twice a day for 2 weeks compared to the control group, which did not receive anthocyanins [133].

In a general way, the antimicrobial, antifungal, and anti-parasitic activities of the anthocyanins are mainly due to their capacity to react with the DNA, proteins, and sulfhydryl groups and interfere with AKT, ATPase, and superoxide dismutase activities, which, in turn, decrease the citric acid cycle and microbial metabolism, and inhibit microbial enzymes $[125,132]$. These events deprive microorganisms of the substrate that they need, compromising their development and replication, the formation of biofilms and host ligand adhesion, and lead to cytoplasmatic membrane destabilization and consequent cell death.

\subsection{Antioxidant Properties}

Free radicals are a product of natural metabolism; however, their accumulation becomes toxic to cells and trigger many reactions, such as the oxidation of cellular components (nucleic acids, proteins, and fatty acids) and lipid peroxidation, accelerating aging processes, and eliciting the occurrence of many chronic diseases, such as neurodegenerative and cardiovascular disorders, cancer, atherosclerosis, and ulcerative colitis [4]. These reactive species can be derived from oxygen (e.g., hydroxyl, peroxyl, and superoxide) or nitrogen (e.g., nitric oxide and peroxynitrite). Besides, there are also even-numbered free radical species, such as $\mathrm{H}_{2} \mathrm{O}_{2}$ and lipid peroxide. Since synthetic antioxidants have various 
adverse effects on health, there is a trend towards relying on antioxidants from natural products. Currently, the notable antioxidant properties of anthocyanins are well-described, and it is mainly due to their conjugated rings and hydroxyl groups [41,134,135].

Many in vitro assays already demonstrated the antioxidant potential of anthocyanin derivatives and foods rich in them [136]. Focusing on individual anthocyanins, Rahman et al. [137] reported that delphinidin isolated from blueberry extracts shows the most considerable capacity to scavenge superoxide species, followed by petunidin $>$ malvidin $=$ cyanidin $>$ peonidin $>$ pelargonidin, at $1 \mu \mathrm{M}$. Similar results were obtained, regarding the capacity of these compounds, at the same concentration, to capture peroxynitrite radicals [133]. Moreover, cyanidin 3-O-glucoside at concentrations between 100 and $200 \mu \mathrm{M}$ showed potential to protect human keratinocyte $\mathrm{HaCaT}$ cells against ultraviolet-A radiation, preventing DNA fragmentation and the release of hydrogen peroxide $\left(\mathrm{H}_{2} \mathrm{O}_{2}\right)$ [138].

Regarding the anthocyanin-enriched fractions from natural products, extracts of blackberries, blueberries, strawberries, sweet cherries, and red raspberries at $10 \mu \mathrm{M}$ displayed the potential to inhibit human LDL oxidation, having been two times more effective than an ascorbic acid control [139]. The coloured fraction of the sweet cherries also showed capacity to scavenge nitric oxide, in a concentration-dependent manner, displaying a halfmaximal inhibitory concentration $\left(\mathrm{IC}_{50}\right)$ value of $47.44 \mu \mathrm{g} / \mathrm{mL}$, being three times more active than ascorbic acid $\left(\mathrm{IC}_{50}=179.69 \mu \mathrm{g} / \mathrm{mL}\right)$; it also protects human erythrocytes against haemoglobin oxidation and prevents haemolysis damage induced by peroxyl radicals, in a concentration-dependent manner ( $\mathrm{IC}_{50}=33.86$ and $9.44 \mu \mathrm{g} / \mathrm{mL}$, respectively). Positive correlations $(r>0.4)$ between anthocyanin content and antioxidant assays have been reported [134]. Additionally, the same extract also exhibited potential to capture superoxide species in a concentration-dependent manner ( $25 \%$ inhibitory concentration $\left(\mathrm{IC}_{25}\right)$ score of $16.58 \mu \mathrm{g} / \mathrm{mL}$ ) and protect human adenocarcinoma Caco-2 cells against oxidative stress induced by tert-butyl hydroperoxide [130]. Blackberries extracts rich in anthocyanins revealed a ferric-reducing antioxidant power score of $191 \mu \mathrm{Mol} \mathrm{Fe}^{2+} / \mathrm{L}$ (extract concentrations between 10 and $200 \mu \mathrm{g} / \mathrm{mL}$ ) [138] and also capacity to quench peroxyl radicals (4885 $\mu \mathrm{Mol}$ Trolox equivalent/g) [140]. After $24 \mathrm{~h}$ of treatment, the same extract, at concentrations varying between 0.02 and $50 \mu \mathrm{g} / \mathrm{mL}$, also showed an ability to protect human intestinal INT-407 normal cells against intracellular oxidation induced by 2,2 '-azobis(2amidinopropane) dihydrochloride $\left(\mathrm{IC}_{50}=4.1 \mu \mathrm{g} / \mathrm{mL}\right.$ ) [140]. Blackberry and raspberry fruits also revealed lipid peroxidation inhibitory potential, displaying $\mathrm{IC}_{50}$ values lower than $50 \mu \mathrm{g} / \mathrm{mL}$ [141].

Concerning in vivo trials, delphinidin ( $1 \mathrm{mg} / 0.1 \mathrm{~mL}$ DMSO/mouse) showed capacity to protect mouse skin against UV-B radiation, preventing apoptosis after $8 \mathrm{~h}$ of exposure [142]. Additionally, rats that were fed during 35 days with anthocyanin extracts ( $4 \mathrm{mg} / \mathrm{kg}$ of body weight) from blackberries showed a meliorate antioxidant status compared to animals that did not receive these phenols in the diet, with lower levels of reactive species in the brain, liver, kidney, and plasma standing out $(-35 \%,-44 \%,-17 \%$ and $-8 \%$, respectively), as well as higher catalase and glutathione peroxidase concentrations in the brain, kidney, and liver $(+0.30,+0.65$ and $+0.05 \%$, respectively) [143]. Anthocyanins from dabai fruits also showed potential to increase superoxide dismutase action $(+10 \%)$ and to inhibit lipid peroxidation $(-21 \%)$ in white rabbits that ingested $2000 \mathrm{mg} /$ day of the extract for 8 weeks, compared to the control group. These benefits are attributed to the ability of anthocyanins to disrupt the activity of poly(ADP-ribose) polymerase 1 [144].

In humans, the ingestion of fresh strawberry fruits ( $300 \mathrm{~g}$, possessing $9.57 \mathrm{mg}$ of anthocyanins) by 13 healthy volunteers revealed the capacity to increase the plasma ferric-reducing antioxidant power $(+3.1 \%), \alpha$-carotene $(+7 \%)$, and vitamin C $(+23 \%)$ levels [145]. Besides, 12 healthy participants who consumed açaí juice and pulp, composed of $165.9 \mathrm{mg} / \mathrm{L}$ and $303.8 \mathrm{mg} / \mathrm{kg}$ of anthocyanins, respectively, showed increments in plasma antioxidant capacity of 3- and 2.3-fold, respectively [11]. Furthermore, forty-seven healthy adults who consumed $30 \mathrm{~mL}$ of tart cherry concentrate diluted to a volume of $250 \mathrm{~mL}$ with water for 6 weeks showed higher levels of plasma ferric-reducing ability 
than the control group (+10\%) [12]. A randomised cross-over study involving 30 healthy female participants who drank $330 \mathrm{~mL}$ of an anthocyanin-rich beverage over 14 days displayed increases in superoxide dismutase activity of about $6 \%$, compared to the placebo group [146]. More recently, $300 \mathrm{~g}$ of blueberries ingested by ten young volunteers showed potential to protect human blood mononuclear cells against oxidative damage induced by $\mathrm{H}_{2} \mathrm{O}_{2}$ compared to the control, by reducing oxidative damage by $18 \%$ after $24 \mathrm{~h}$ of their consumption [147]. The same was verified after a 30-day-treatment with $500 \mathrm{~g}$ of strawberry fruits [148]. Anthocyanin-rich juices and nectars also showed potential to aid recovery after strenuous exercise by increasing the plasma total antioxidant capacity and diminishing lipid peroxidation and carbonyl species [149-151].

These considerable health-promoting properties are intimately linked to the capacity of anthocyanins to increase the glutathione levels by restoring or raising the activity of exogenous antioxidant enzymes and by activating the genes responsible for coding these enzymes. Besides, it is also due to their ability to inhibit NADPH and xanthine oxidases and modify arachidonic metabolism and mitochondrial respiration, and hence, reduce the formation of free radicals and reactive species, protecting cell components from damage [41]. Furthermore, anthocyanins can enter into cells and activate the Nrf2/HO1 pathway, conferring resistance against oxidative damage and increasing antioxidant defence [152], and can interact with other natural antioxidants, such as other phenolic compounds, carotenoids, and vitamins, which also increase their ability to relieve oxidative stress [134]. Nevertheless, and although no study has revealed toxicity on humans, it is imperative to conduct further in vivo studies in order to reveal the safe dosage of phenolics intake, including of anthocyanins and anthocyanidins, as they can act as pro-oxidants in some conditions (e.g., a basic $\mathrm{pH}$, high concentrations of transition metal ions, and the presence of oxygen, among others) [153].

\subsection{Anti-Inflammatory Properties}

Anthocyanins also possess anti-inflammatory capacity. Inflammatory conditions happen in response to pathogens that were not removed (e.g., autoimmunity) or due to an inadequate long-term response to stimuli (e.g., allergies). They are characterized by oedema, redness, pain, fever, function losses, and larger amounts of pro-inflammatory cytokines (e.g., tumour necrosis factor (TNF)- $\alpha$, interleukin (IL)-6, and $1 \beta$ ) and nitric oxide radicals [154]. Therefore, it is important to be treated as soon as possible given their involvement in chronic disorders, such as asthma, obesity, gout, diabetes, cancer, atherosclerosis, and neurological pathologies.

Among the anthocyanins, cyanidin and delphinidin 3-O-glucosides already exhibited potential to reduce the C-reactive protein levels by $77 \%$ in human liver cancer HepG2 cells, and vascular cell adhesion molecule- 1 secretion in endothelial cells by $47 \%$, at concentrations of $50 \mu \mathrm{g} / \mathrm{mL}$ compared to the non-exposed cells group [13]. Additionally, delphinidin, petunidin, and malvidin 3,5-diglucosides also revealed capacity to inhibit nitric oxide release, and IL-6, IL- $1 \beta$, and TNF- $\alpha$ in lipopolysaccharide (LPS)-induced RAW264.7 macrophages at concentrations of $80 \mu \mathrm{g} / \mathrm{mL}$ [152]. Anthocyanin extracts from raspberries (concentrations of 100,150, and $200 \mu \mathrm{g} / \mathrm{mL}$ ) also showed an ability to reduce the expression levels of cyclooxygenase-2 (COX-2), inducible nitric oxide synthase (iNOS), and IL $1 \beta$ and IL-6, and to suppress AP-1 signalling and nuclear factor kappa B (NF-kB) pathways. Additionally, it was also verified that they can decrease IKK, IkBa, p65, and JNK phosphorylation, avoid p65 nuclear translocation in LPS/IFN- $\gamma$-stimulated RAW 264.7 macrophage cells [155], and inhibit lipoxygenase activity, at concentrations of 10, 25, and $50 \mu \mathrm{g} / \mathrm{mL}$ [154]. Similar results were obtained concerning the anthocyanins isolated from strawberries and blackberries at a concentration of $50 \mu \mathrm{g} / \mathrm{mL}$ [156], and purple sweet potato at $200 \mu \mathrm{g} / \mathrm{mL}$ [152]. Besides, anthocyanin-fractions extracted from berries also showed potential to reduce TNF- $\alpha$, IL-8, and Regulated upon Activation, Normal T Cell Expressed and Presumably Secreted (RANTES) at doses between 10 and $25 \mu \mathrm{g} / \mathrm{mL}$ in human bronchial epithelial BEAS-2B normal cells treated with LPS [157]. These results are in line 
with those recently described by Chen et al., who proved that an anthocyanin-rich extract from mulberry fruits, at a concentration of $50 \mathrm{mg} / \mathrm{mL}$, can reduce the IL-6, iNOS, phosphop65, and phospho-I $\mathrm{B} \alpha$ pro-inflammatory markers, and increase the IL-10 concentration in RAW264.7 macrophage cells stimulated with LPS over $24 \mathrm{~h}$ of exposure [128].

Enriched fractions of anthocyanins from raspberries already showed anti-inflammatory effects in dextran sulphate sodium-induced acute colitis in mice. Animals ingested $20 \mathrm{mg} / \mathrm{kg}$ of the extract for 10 days. At the end of the study, blood samples were collected, and mice were sacrificed for histological assessment. The results were compared in the control group; i.e., rats only received a normal diet. The obtained data revealed that a diet rich in anthocyanins contributed to improve colitis damage, by enhancing proinflammatory markers reduction and controlling weight [155]. Similar data were observed by Pereira et al. [158], who's study was based on the administration of blueberries also in 2,4,6-trinitrobenzenesulfonic acid-induced colitis rat models, at concentrations of $10 \mathrm{mg} / \mathrm{kg}$ over 8 days of treatment, compared to an untreated group. This study proved the ability of anthocyanins to downregulate iNOS, inhibit COX-2 expression, decrease leukocyte infiltration, and increase antioxidant defence in the colon. Tart cherry anthocyanins $(400 \mathrm{mg} / \mathrm{kg}$ ) administrated for 3 days also showed an ability to suppress inflammation-induced pain in rats, essentially due to their ability to inhibit cyclooxygenase-mediated synthesis of prostaglandins [159]. Furthermore, Kim et al. revealed that $5 \mathrm{mg}$ of encapsulated anthocyanins per day can decrease COX-2, NOS3, IL- $1 \beta$, and TNF- $\alpha$ inflammatory cytokines in mice brain [121]. Another study related to anthocyanins extracted from rice (at $25 \mu \mathrm{g} / \mathrm{mL}$ ) proved that they can increase type I collagen gene expression and protect skin fibroblasts against $\mathrm{H}_{2} \mathrm{O}_{2}$ damage, essentially by inhibiting $\mathrm{I} \kappa \mathrm{B} \alpha$ phosphorylation, NF- $\kappa \mathrm{B}$ activation, and IL-6 production, over $24 \mathrm{~h}$ of exposure [160].

Regarding human studies, 150 hypercholesterolemic subjects who ingested $320 \mathrm{mg}$ anthocyanin capsules, rich in cyanidin 3-O-glucoside and delphinidin 3-O-glucoside, daily for 24 weeks showed lower levels of $C$-reactive protein, vascular cell adhesion molecule-1, and plasma IL- $1 \beta$ levels $(-20,-13$ and $-4 \%$, respectively) when compared to the untreated group. No changes were detected regarding TNF- $\alpha$ concentrations, which indicate that the intervention was safe [13]. Jacob et al. reported that the consumption of $280 \mathrm{~g}$ of cherries (28 mg per $100 \mathrm{~g}$ of fresh weight) twice a day can also reduce the plasma C-reactive protein and nitric oxide levels by $29.4 \%$ and $16.8 \%$, respectively, when compared with the baseline. A decrease in plasma urate $(-14.5 \%)$ and increments in ascorbic acid $(+9 \%)$ were also verified, highlighting the anti-gout effects of cherries. This trial was composed of ten healthy women who consumed cherries after an overnight fast [161]. These data are in accordance with Kelley et al., who conducted a study involving 18 healthy men and women that were subjected to the daily consumption of $280 \mathrm{~g}$ cherries for 28 days. The results revealed a decrease in C-reactive protein, nitric oxide, and RANTES at percentages of -25 , -18 and $-21 \%$, respectively. No changes were observed in IL-6, neither in the high-, low-, and very-low-density lipoprotein cholesterols nor triglycerides, which can be considered evidence regarding the security of this supplementation dose [162]. Furthermore, ten healthy adult volunteers who drank $10 \mathrm{~g}$ of Hibiscus sabdariffa diluted in water showed lower monocyte chemoattractant protein-1 $(-23.2 \%)$ levels, an important biomarker considering the evaluation of inflammatory disorders, after $3 \mathrm{~h}$ of their consumption compared to the placebo group [163]. Additionally, a pilot study, composed of 13 patients with mild to moderate ulcerative colitis, consumed $160 \mathrm{~g}$ of blueberries ( 4 trays per day), corresponding to $95 \mathrm{~g} \mathrm{dw}$ (around $600 \mathrm{~g}$ of fresh fruit) during six weeks, revealed that $63.4 \%$ of patients achieved remission of the inflammatory bowel disease [164]. In another study, sixteen volunteers were subjected to the consumption of a $250 \mathrm{~mL}$ dose of anthocyanin-rich plum juice; the results obtained revealed a decrease in the C-protein reactive, IL-6, IL- $1 \beta$, and TNF- $\alpha$ concentrations of $-22,-7,-9$ and $-4 \%$, respectively. These data were observed $4 \mathrm{~h}$ after the intake relative to the placebo group [165].

Besides the mentioned, anthocyanins also facilitate muscle recovery after intense exercise, attenuating its damage and inflammation [149-151]. Indeed, sixteen active students 
who drank $480 \mathrm{~mL}$ of blackcurrant nectar for eight consecutive days revealed lower levels of creatine kinase, a marker of muscle damage, and IL-6, $48 \mathrm{~h}$ post physical activity [149]. These results were similar as those obtained by Hurst et al. also based on the consumption of blackcurrant nectar ( $240 \mathrm{mg}$ total anthocyanins). In this work, a 5-week randomized placebo-controlled pilot trial composed of 36 volunteers revealed that the group who consumed this juice showed lower levels of pro-inflammatory TNF- $\alpha$ and IL- 6 molecules and increments in anti-inflammatory IL-10 cytokines [151]. Furthermore, twenty runners who consumed $30 \mathrm{~mL}$ of tart cherry juice during 5 days before and $48 \mathrm{~h}$ after a marathon run also showed reduced levels of inflammatory markers (IL-6, uric acid, and C-protein reactive) compared to the placebo group [150].

These effects are closely linked to the ability of anthocyanins to prevent CD40 activation, a member of the tumour necrosis factor receptor superfamily [166]. Additionally, they also can inhibit the cyclooxygenase isoenzymes, COX-1 and COX-2, and interfere with the MAPK cascade [121]. Indeed, and through an in vitro cyclooxygenase inhibitory assay with enzymes from ram seminal vesicles, anthocyanins extracted from sweet cherries and raspberries, at a concentration-dose of $125 \mu \mathrm{g} / \mathrm{mL}$, showed more potential to inhibit COX-1 activity (47.4 and 54.3\%, respectively) than ibuprofen (39.8\%) and naproxen (41.3\%) at $10 \mu \mathrm{M}$ [167].

\subsection{Anticancer Properties}

Cancer causes more deaths than strokes and coronary disorders and it is characterized by uncontrolled cell growth and proliferation [8]. Anthocyanins have demonstrated capacity to inhibit the initiation, promotion, and progression of types of cancer, such as human colon [134,168], liver and bladder [169,170], breast [171], brain [172], renal and skin [168], gastric [141], and thyroid [173] cancers, mainly due to their antioxidant properties and capacity to interfere with PI3K/Akt [174].

The capacity of anthocyanins to inhibit the growth of metastatic cells is not surprising. Indeed, the enriched fraction of anthocyanins from sweet cherries already showed an ability to inhibit human adenocarcinoma Caco-2 cells growth (inhibitory $\mathrm{IC}_{50}$ value of $667.84 \mu \mathrm{g} / \mathrm{mL}$ ), causing necrosis at concentrations superior to $400 \mu \mathrm{g} / \mathrm{mL}$, after $24 \mathrm{~h}$ of treatment [134]. Similar effects were verified using coloured phenolics from pollen, but at a higher concentration $(10 \mathrm{mg} / \mathrm{mL})$ [175]. Concentrations higher than $500 \mu \mathrm{g} / \mathrm{mL}$ of anthocyanin-rich extracts from the Myrtaceae family also showed an ability to reduce the proliferation of human colon adenocarcinoma HT-29 cells, mainly by arresting the G2/M phase, hence causing cell apoptosis in comparison with the control group over $24 \mathrm{~h}$ of treatment [176]. It was also already verified that anthocyanin-rich extracts from pomegranate at $50 \mu \mathrm{g} / \mathrm{mL}$ can reduce by $10 \%$ the growth of human bladder cancer T24 cells growth after $48 \mathrm{~h}$ of exposure, in comparison with untreated cells [170]. Additionally, and after 2 days of an incubation assay, anthocyanins from cherries also showed capacity to interfere with MDA-MB-453 and MDA-MB-231 breast cancer cell lines growth, revealing $\mathrm{IC}_{50}$ values of 45 and $149 \mu \mathrm{g} / \mathrm{mL}$, respectively, without toxicity to MCF-10A normal breast cells [171]. Blackberry and raspberry fruits at $250 \mu \mathrm{g} / \mathrm{mL}$ also revealed effectiveness in stopping cancer cell growth, inhibiting human colon HCT-116, breast MCF-7, lung NCIH460, and gastric AGS tumour cell lines by 50, 24, 54, and 37\%, respectively, after $24 \mathrm{~h}$ of exposure [141]. Furthermore, $10 \mu \mathrm{g} / \mu \mathrm{L}$ of anthocyanins from mulberries revealed capacity to suppress thyroid SW1736 and HTh-7 cancer cell proliferation, by inducing apoptosis and autophagy-dependent cell death, and inhibiting protein kinase B and ribosomal protein S6 activation, after $72 \mathrm{~h}$ of treatment [173]. On the other hand, açaí extracts rich in anthocyanins showed the ability to suppress C-6 rat brain glioma cell growth, showing cell viability reductions of 62,45 , and $38 \%$ at concentrations of 50,100 , and $200 \mu \mathrm{g} / \mathrm{mL}$, respectively, after $48 \mathrm{~h}$ of treatment [172]. More recently, Vilkickyte et al. reported that anthocyanins isolated from lingonberry fruits can suppress the viability of malignant melanoma IGR39 and renal CaKi-1 cancer cells, displaying IC 50 values of 200 and $400 \mu \mathrm{g} / \mathrm{mL}$, respectively [168]. 
Focusing on in vivo studies, the daily administration of berries $(0.5 \mathrm{mg} / \mathrm{kg}$ body weight) in rats with induced oesophageal carcinoma showed an ability to reduce cancer growth by $22 \%$ over 20 weeks of treatment, when compared to the control group [177]. Adding $10 \%$ dietary freeze-dried berries to the standardized diet of rats also showed capacity to inhibit induced oesophagus cancer by $30-60 \%$ and colon cancer by up to $80 \%$ when compared to the control, over 25 weeks of treatment [178].

Furthermore, a recent study revealed that anthocyanins from blueberry extracts showed the capacity to prevent the formation and growth of colorectal cancer in azoxymethane/dextran sodium sulphate-treated Balb/c mice, which ingested a diet containing $10 \%$ of the extract during 9 weeks of treatment, compared with the control [179]. Anthocyanins from Vitis coignetiae Pulliat also showed the potential to inhibit the tumorigenicity in mice infected with Hep3B human hepatocellular carcinoma cells $(5 \mu \mathrm{g} / \mathrm{g}$ of animal per day) [180].

On the other hand, berry anthocyanins displayed anticarcinogenic effects on lung cancer progression in rat xenograft models (reductions around $40 \%$ ) treated with a diet supplemented with $7.5 \%$, after 6 weeks of the intervention [181]. The supplementation during 1 month with $0.5 \%$ of cyanidin and peonidin 3-O-glucosides also exhibited the capacity to reduce Lewis lung carcinoma cells in mice [182].

In addition, the administration of delphinidin ( $2 \mathrm{mg}$, three times a week) in athymic nude mice implanted with PC3 cells resulted in significant inhibition of prostate tumour growth, essentially by reducing the expression of NF- $\mathrm{KB} / \mathrm{p} 65, \mathrm{Bc} 2$, Ki67, and PCNA after 8 weeks of treatment [183]. An anthocyanin mixture extracted from black soybean also inhibited xenograft growth of prostate cancer in mice treated with a daily oral anthocyanin $(8 \mathrm{mg} / \mathrm{kg})$ after 14 weeks of intervention [184].

Besides, the daily administration of anthocyanin-rich extracts from black rice (100 mg $/ \mathrm{kg}$, during 28 weeks) in mice xenografted with human tumour models showed the ability to reduce breast cancer growth, causing reductions around $41 \%$ [185], mainly due to their ability to inhibit growth factor receptor 2, a gene overexpressed in this type of cancer [186]. Blackthorn fruits at $0.2 \mathrm{mg}$ daily (5 days a week, for one month) already showed potential to slow down tumour growth xenografts in immunodeficient mice injected with human colon HCT116 cancer cells [187]. Anthocyanins from black rice already showed potential to increase immune responses in murine leukaemia cells, at concentrations higher than $50 \mathrm{mg} / \mathrm{kg}$ over 3 weeks of treatment, promoting CD3 (T cell), CD19 (B cell), CD11b (monocyte), and macrophage phagocytosis, and decreasing the NK cell activity when compared to the untreated control group [188].

Regarding skin cancer, the administration of anthocyanins extracted from Sorbus aucuparia $(5 \mathrm{~mL} / \mathrm{kg}$ for 11 days) in rats showed potential to reduce melanoma [189]. Furthermore, Lee et al. reported that anthocyanins extracted from aronia conjugated with fucoidan, a natural polysaccharide extracted from seaweed, can prevent the development of induced skin tumour in mice when administered twice a week at a concentration of $900 \mathrm{mg} / \mathrm{kg}$ dose during 22 weeks [174].

Although there are no relevant studies regarding the anti-cancer effects on humans, it was already verified that the consumption of $20 \mathrm{~g}$ of black raspberry powder for between 2 and 4 weeks (three times per day) by Barrett's oesophagus patients, a precursor lesion for oesophageal tumour, can reduce the proliferation rates and CD 105-stained blood vessels, and increase apoptosis in colon tumours [190].

The ability of anthocyanins to inhibit the initiation and development of a tumour is closely associated with their ability to increase antioxidant defences, exert anti-inflammatory actions, and interfere with the ERK, JNK, PI3K/Akt, MAPK, and NF-KB pathways, as well as being associated with their regulated proteins and influence on the estrogenic/antiestrogenic levels [180,183]. Furthermore, these flavonoids compounds also showed apoptotic effects since they can activate the caspase cascade, reduce the mitochondria membrane potential, and modulate the cytochrome $\mathrm{C}$ and aromatase activities [185,191]. 


\subsection{Neurological Properties}

Knowing neurological pathologies are closely related to oxidative stress and inflammatory levels, it is not surprising that the consumption of secondary metabolites from plants, such as anthocyanins, can reduce their occurrence.

Anthocyanin-enriched fractions extracted from berries at $20 \mu \mathrm{g} / \mathrm{mL}$ already showed capacity to reduce nitric oxide, reactive oxygen, and carbonyl species, as well as the $\mathrm{H}_{2} \mathrm{O}_{2}$ levels and apoptotic protease caspase-3/7 activity in BV-2 microglia cells in about 20\% relative to untreated cells. They also showed an ability to diminish anti-glycation and anti-A $\beta$ A aggregation [192]. Furthermore, anthocyanin-rich extracts from blueberries at $0.01 \mu \mathrm{g} / \mathrm{mL}$, together with cyanidin 3-O-glucoside, cyanidin 3-O-sophoroside, delphinidin 3-O-glucoside, and malvidin 3-O-glucoside at $1 \mu \mathrm{M}$, also revealed an ability to protect dopaminergic neurons from the primary cells of Parkinson's disease against rotenone toxicity, after $72 \mathrm{~h}$ of treatment, essentially by attenuating mitochondrial dysfunction [193].

Besides, it was already reported that anthocyanins (ingestion of $100 \mathrm{mg} / \mathrm{kg}$ for 10 months) can restore the ion pump activities in rats experimentally demyelinated with ethidium bromide, by diminishing the proinflammatory mediators' secretion and oxidativestress levels and restoring the IL-10 levels [131]. Additionally, anthocyanins isolated from black bean at concentrations varying from 100 and $200 \mu \mathrm{g} / \mathrm{mL}$ (over $12 \mathrm{~h}$ of treatment) proved their ability to protect the hippocampal neurons of mice against toxicity induced by kainic acid, mainly thanks to their capacity to reduce the reactive oxygen species levels, caspase-3, AMPK activation, and mitochondrial cytochrome-c release into the cytoplasm, and in attenuating the $\mathrm{Ca}^{2+}$ perturbations, losses of mitochondrial integrity, and Bax accumulation [194]. Kim et al. revealed that $5 \mathrm{mg}$ (administered during 14 days) of anthocyanins encapsulated in gold nanoparticles can cross the blood-brain barrier and reduce the amyloid- $\beta_{1-42}$ plaques and neuro-apoptotic markers (anti-Bax, anti-Bcl2, anti-caspase-3, anti-cytochrome c, and anti-P-JNK) by inhibiting the $\rho$-JNK/NF- $\kappa \mathrm{B} / \rho-\mathrm{GSK} 3 \beta$ pathway in mice brain [121].

Concerning human assays, a 12-week randomised study involving 49 older adults with mild-to-moderate dementia who drank $200 \mathrm{~mL}$ anthocyanin-rich cherry juice showed improvements in verbal fluency, learning, memory, and cognition when compared to the untreated group [14]. Similar neurological improvements were observed after 12 weeks of blueberry concentrate supplementation in healthy older adults, who drank $30 \mathrm{~mL}$ of blueberry juice compared to the placebo [15]. Whyte et al. also conducted a study involving one hundred and twenty-two older adults, which consumed 16 capsules per week over 3 months of blueberry-rich extracts. As expectable, better cognitive tasks regarding executive function, working memory, and episodic memory were registered in comparison to the placebo [195].

As mentioned before, the neuroprotective effects showed by anthocyanins are mainly due to their ability to cross the blood-brain barrier and protect neurons and glia cells from oxidative damage induced by reactive species and free radicals, reduce the inflammatory cytokines and $\beta$-amyloid concentrations, and to suppress NF- $k$ B, the Nf E2-related factor-2 (Nrf-2) signalling pathway, COX, and caspase activities [119]. Furthermore, anthocyanins also can raise gene expression, GTPase activity, and detoxifying enzyme amounts, and therefore meliorate cerebrovascular and peripheral blood flow [196].

\subsection{Anti-Diabetic and Anti-Obesity Effects}

Diabetes mellitus, with type 2 standing out, affects several people worldwide, being associated with obesity, oxidative stress, inflammatory events, and cardiovascular risk [197]. Given the resistance developed to the current pharmaceutical drugs administrated, the ingestion of anthocyanin-rich products has been encouraged. In fact, anthocyanins already showed mechanisms capable to diminish insulin resistance, hyperglycaemia, proinflammatory cytokines, and radical species; inhibit gluconeogenesis and the action of the $\alpha$-amylase and $\alpha$-glucosidase carbohydrate-hydrolysing enzymes; and, consequently, restore the glucose levels, incentive insulin secretion, and pancreatic $\beta$-cells proliferation $[198,199]$. 
Among the anthocyanins, cyanidin 3-O-glucoside already showed potential to inhibit pancreatic $\alpha$-amylase activity, revealing an $\mathrm{IC}_{50}$ value of $24.4 \mu \mathrm{M}$ [200]. Anthocyaninenriched fractions from sweet cherries also showed the capacity to inhibit the $\alpha$-glucoside action, showing to be three times more efficient than the acarbose control, which is the current pharmaceutical drug used to treat type 2 diabetes, but whose intake cause several gastrointestinal side effects [134]. Besides, anthocyanins from Cornus kousa displayed anti-angiogenic effects in the pre-adipocyte cell line 3T3-L1s, suppressing lipogenesis and adipogenesis in comparison with untreated cells after 8 days of exposure [201].

The oral administration of acarbose combined with cyanidin 3-O-rutinoside $(30 \mathrm{mg} / \mathrm{kg})$ also revealed an ability to alleviate postprandial hyperglycaemia and inhibit intestinal $\alpha$-glucosidase in normal rats over three hours of intervention, as compared with the control group [202]. Besides, it was already documented that the glucoside of cyanidin can also meliorate diabetes-related endothelial dysfunction in mice that received a $6 \mathrm{mg} / \mathrm{kg}$ diet for 8 weeks, by stimulating adiponectin expression and improving flow-mediated dilation [203]. On the other hand, black currant anthocyanins showed the ability to reduce body weight gain and glucose levels and improve insulin sensitivity in mice that were fed with $8 \mathrm{mg} /$ day of anthocyanins for 8 weeks. Converted into human equivalent doses, these ones are estimated to be $1.5 \mathrm{~g} /$ day of total anthocyanins for an average adult [56]. Furthermore, the daily administration of anthocyanins from Hibiscus sabdariffa L. (300 mg/kg) in obese-hypercholesterolemic rats revealed the capacity to reduce their weight, as well as to improve their lipid profile and liver enzymes action over 3 weeks of treatment in comparison to the group that did not receive the diet [198]. Blueberry anthocyanins also showed anti-obesity effects. Indeed, their administration at doses of $200 \mathrm{mg} / \mathrm{kg}$ during one month showed the ability to reduce the body weight of obese C57BL/ 6 mice by $19.4 \%$ and also diminish the glucose and pro-inflammatory levels, improve the lipid profile, and suppress the peroxisome proliferator-activated receptor- $\gamma$, FAS genes, and fatty acid synthesis over a 16-week treatment in contrast to the untreated group [204]. These results were similar as those reported by Kwon et al. and $\mathrm{Wu}$ et al. regarding the oral ingestion of anthocyanins from black soybean, black rice, and purple corn by obese rats $[16,205]$.

Regarding human studies, it was already reported that twenty dyslipidaemic children and adolescents who daily ingested $50 \mathrm{~g}$ of cornelian cherry fruits, during 6 weeks, showed better lipid, apolipoprotein and vascular inflammation profiles and lower levels of LDL and triglycerides, intracellular adhesion molecule- 1 and vascular cell adhesion molecule- $1(-10$, $-13,-30$ and $-25 \%$, respectively). Higher levels regarding apolipoprotein A $(+11.6 \%)$ and a diminished content of apolipoprotein B $(-13.6 \%)$ were also verified [197].

The anthocyanins potential to be used as novel therapeutic agents against diabetes and obesity is fundamentally attributed to their chemical structure, which gives them inhibitory effects on the carbohydrate-hydrolysing enzymes' action and capacity to interact in a competitive and/or non-competitive mode with the enzymes' substrate and create hydrophobic bonds with these enzymes, thereby discontinuing their act and retard carbohydrate absorption $[134,200]$. Furthermore, anthocyanins also revealed the capacity to raise GLUT 4 membrane translocation expression and upregulate the signalling pathway of the peroxisome proliferator-activated receptors, encouraging adipocyte glucose uptake and improving the lipid profile [10].

\subsection{Cardiovascular Properties}

Cardiovascular pathologies are the principal cause of morbidity and mortality worldwide. They are intimately associated with the adoption of unhealthy behaviours, such as smoking, excessive alcohol intake, and other risk factors, including metabolic syndrome [33]. Several studies indicate that the daily intake of anthocyanin-rich fruits, vegetables and beverages can attenuate, or even prevent, the occurrence of coronary events, since they can modulate lipid metabolism, fat deposition, and endothelial function, as well as reduce blood pressure and vascular adhesion molecules expression. These activities are intimately associated with their antioxidant and anti-inflammatory characteristics [206]. 
Particularly, cyanidin 3-O-glucoside and delphinidin 3-O-glucoside at concentrations of $50 \mu \mathrm{M}$ showed the ability to reduce in vitro platelet aggregation and lysosome secretion, essentially by reducing $\beta$-thromboglobulin, serotonin ATP, platelet factor 4, CD63, and transforming growth factor $\beta 1$ secretion after $40 \mathrm{~min}$ of exposure [207]. Moreover, it was already documented that cyanidin 3-O-glucoside can stimulate adiponectin expression and improve flow-mediated dilation in human adipose tissues and human aortic endothelial cells treated with $50 \mu \mathrm{M}$ of cyanidin 3-O-glucoside after $24 \mathrm{~h}$ of exposure [203]. Blueberry anthocyanidins (cyanidin, delphinidin, and malvidin) are also reported to inhibit human umbilical vein endothelial cell-induced tube formation in a co-culture with fibroblasts at concentrations ranging from 0.3 and $10 \mu \mathrm{M}$ [208].

Moreover, $50 \mu \mathrm{g} / \mathrm{mL}$ of anthocyanin-enriched fractions from strawberries already showed capacity to reduce the triglycerides and low-density lipoprotein (LDL) contents around $17 \%$ and $23 \%$, respectively, in HepG2 cells after $24 \mathrm{~h}$ of treatment [169]. Additionally, $50 \mathrm{mg} / \mathrm{mL}$ of encapsulated anthocyanins extracted from blueberries and black currants already showed the potential to inhibit platelet aggregation by suppressing P-selectin expression and stimulate the thromboxane A2 pathway [209].

Concerning in vivo trials, it was already reported that blueberry anthocyanin-enriched extracts can attenuate cyclophosphamide-induced cardiac damage in rats, treated with $80 \mathrm{mg} / \mathrm{kg}$ during four weeks by ameliorating the arterial blood pressure, heart rate, and activities of the heart enzymes, and improving cardiac dysfunction, left ventricular hypertrophy, and fibrosis. Additionally, they also showed the potential to prevent cardiomyocyte apoptosis [206].

Furthermore, 31 pre-hypertensive men who ingested a single dose of $640 \mathrm{mg}$ anthocyanins daily for 4 weeks revealed higher levels of high-density lipoprotein (HDL) concentrations and lower concentrations of triglycerides [210]. Moreover, the consumption of two capsules ( $80 \mathrm{mg}$ each per day during 28 days) rich in anthocyanins already showed the ability to reduce monocyte-platelet aggregate formation $(-39 \%)$, procaspase activating compound-1 $(-10 \%)$, P-selectin $(-14 \%)$, and inhibit platelet endothelial cell adhesion molecule-1 expression (-14\%) [17]. In another work, the authors reported that the consumption of $250 \mathrm{~g}$ per day of blueberry powder, for 6 weeks, by 13 volunteers showed an ability to increase natural killer cells and reduce arterial stiffness in sedentary males and females, mainly by diminishing diastolic pressure [211]. This fact is in accordance with Whyte et al. [195]. These authors conducted a study involving 122 volunteers who consumed 16 capsules per week of blueberry-rich extracts ( $100 \mathrm{mg}$ of anthocyanins/capsule) over six months. Habanova et al. reported a study of 36 volunteers who consumed $150 \mathrm{~g}$ of frozen blueberries 3 times a week, for 6 weeks. The obtained results revealed lower levels of LDL glucose albumin, aminotransferase, alkaline phosphatase, and $\gamma$-glutamyltransferase, accompanied by higher levels of HDL when compared to the baseline [212]. These data are in line with that reported by Arevström et al., who conducted a study based on the daily ingestion of $40 \mathrm{~g}$ of blueberries powder (equivalent to $480 \mathrm{~g}$ fresh blueberries) over 8 weeks of treatment [213]. Additionally, reductions around 5\% in systolic and diastolic blood pressures were also observed in older adults with mild-to-moderate dementia who drank $200 \mathrm{~mL}$ anthocyanin-rich cherry juice for 12 weeks [156]. Similar results were reported by Draijer et al., who conducted a human trial involving 60 subjects who consumed 6 grape-wine extract capsules ( $247.3 \mathrm{mg}$ anthocyanins per capsule) every day over ten weeks. Additionally, a reduction in endothelin- 1 by $10 \%$ was also found compared to the control group [214]. The obtained results are in line in those obtained by Igwe et al., who conducted a pilot cross-over study involving 24 adults, but who focused on the intake of $100 \mathrm{~mL}$ of anthocyanin-rich plum juice three times a day [215]. Besides, the dietary supplementation of $500 \mathrm{mg}$ of aronia extracts over 12 weeks also revealed the capacity to modulate the lipid profile by diminishing the fasting plasma total cholesterol $(-8 \%)$, LDL, $(-11 \%)$ and LDL receptor protein in peripheral blood mononuclear cells $(-31.9 \%)$, as compared to placebo group. Significant correlations between the obtained results and cyanidin 3-O-galactoside and peonidin 3-O-galactoside contents were found [216]. Similar 
results were reported by Bakkar et al., who conducted a study involving twelve overweight middle-aged men that consumed $226 \mathrm{mg}$ of encapsulated anthocyanins from tart cherries daily for 28 days [217]. Furthermore, blueberries also showed the potential to reduce the peak postprandial glucose levels and extend the postprandial glucose response in 17 healthy young adults who consumed a range of doses varying from 310 and $724 \mathrm{mg}$ of freeze-dried wild blueberry powder, $2 \mathrm{~h}$ following their consumption [218]. Beyond that, the oral ingestion of $320 \mathrm{mg}$ of anthocyanins isolated from berries, over 12 weeks, by hypercholesterolemic individuals also showed the potential to increase brachial artery flow-mediated dilation (+10\%) and HDL amounts (+12.8\%), and diminish serum soluble vascular adhesion molecule-1, triglycerides, and LDL concentrations $(-11.6,-4.1$ and $-10.0 \%$, respectively) [219], and also glycated haemoglobin (HbA1c) $(-0.14 \%)$ [118]. Additionally, it has also been mentioned that the intake of four anthocyanins capsules per day (total of $320 \mathrm{mg} /$ day) can reduce plasma $\beta$-thromboglobulin, soluble P-selectin, platelet factor 4 , and transforming growth factor $\beta 1$ levels in hypercholesterolaemic patients for 24 weeks of treatment as compared with the baseline [207]. These positive effects are correlated with the delphinidin 3-O-glucoside and cyanidin 3-O-glucoside concentrations [219]. Similar effects were reported in adults overweight and obese who drank $200 \mathrm{~mL}$ blood orange juice twice a day for 2 weeks [19]. The consumption of one $350 \mathrm{mg}$ capsule every $8 \mathrm{~h}$ for 2 months also showed the potential to meliorate the lipid profile of hyperlipidaemic patients, by reducing the total cholesterol, triglyceride, and LDL by $-27.6,-19.2 \%$, and $-26.3 \%$, respectively, and raising HDL by $+37.5 \%$ when compared with the baseline [220]. On the other hand, seven days' intake of $600 \mathrm{mg}$ per day of blackcurrant extracts containing $210 \mathrm{mg}$ of anthocyanins showed the potential to increase vasodilation, total haemoglobin, and cardiac output, and decrease the muscle oxygen saturation, which is beneficial in improving exercise performance [221].

Therefore, the regular consumption of anthocyanin-rich foods and beverages can contribute to reduce the risk of cardiomyopathies, coronary problems, and ischemia $[8,33]$. These effects are due to the antioxidant and anti-inflammatory effects of anthocyanins, given that nitric oxide radicals and pro-inflammatory cytokines are critical factors in cardiovascular diseases. In fact, these compounds can inhibit p38 mitogen-activated protein kinases, c-Jun N-terminal kinase activation, and the PI3K/Akt signalling pathways, consequently attenuating eNOS phosphorylation and cGMP production, interrupt MAPK activation, and the recruitment of TNF-receptor-associated factors- 2 in lipids, in the way of protecting endothelial cells from CD-40 proinflammatory effects [166].

\subsection{Eye Improvement}

In vivo and in vitro evidence also revealed that anthocyanins can improve the eyes and thus vision, owing to their ability to increase blood circulation in retina capillaries and the production of retinal pigments, which, in turn, improve night vision and protect eyes from oxidative damage, diabetic retinopathy, and molecular degeneration [8].

Anthocyanins isolated from blackberries at $100 \mu \mathrm{g} / \mathrm{mL}$ showed potential to protect human adult retinal pigment epithelial ARPE-19 cells against oxidative stress induced by $\mathrm{H}_{2} \mathrm{O}_{2}$, by increasing the activity of heme-oxygenase- 1 and glutathione S-transferase-pi antioxidant enzymes after $24 \mathrm{~h}$ of exposure [222]. Similar data were reported by Sundalius [223] regarding blueberry anthocyanins, over 7 days of treatment.

Concerning in vivo studies, delphinidin 3-O-rutinoside at $10 \mu \mathrm{M}$ already showed an ability to relax the bovine ciliary smooth muscle through activation of the endothelin-1 receptor and NO/cGMP pathway, inhibiting myosin light chain phosphorylation, hence causing relaxation [224]. Additionally, anthocyanins extracted from black currants showed the potential to inhibit vitreous-chamber depth enlargement, and the axial and ocular lengths of chicks when compared to the controls, over 3 days of treatment at a dose concentration of $200 \mathrm{mg} / \mathrm{kg}$ [225].

Focusing on human assays, a double-blind, placebo-controlled, crossover study involving healthy volunteers revealed that the daily intake of six capsules rich in blackcurrant 
anthocyanins at a concentration of $50 \mathrm{mg}$ can improve dark adaptation, video display terminal work-induced transient refractive alteration, and asthenopia symptoms (visual fatigue) in comparison to the placebo [226]. In another study based on the ingestion of anthocyanins from blueberry, the results revealed that the patients with normal-tension glaucoma presented vision improvement, not only due to anthocyanins' oxidative properties but also owing to their ability to increase the blood circulation [18].

Given that, it was already reported that intact anthocyanins can pass through the blood-aqueous barrier and blood-retinal barrier in rats and rabbits, being widely distributed in ocular tissues [224]. This evidence, together with their antioxidative effects and blood circulation improvements, suggests that anthocyanins can be considered a potential drug therapy for treating ophthalmological diseases, such as myopia and glaucoma $[8,18]$.

\section{Conclusions}

Anthocyanins are the coloured compounds largely found in nature, for which evidence indicates that their regular consumption offers several health benefits to human health, mainly due to their ability to reduce free radicals, reactive species, and pro-inflammatory markers. These abilities can counteract oxidative stress levels, avoid the development of inflammatory processes, and protect human organs and cell components against damage, and thus confer protection at distinct levels. Thus, anthocyanins' structure, biochemistry, and encapsulation have been deeply studied in order to increase their use, stability, and consequent bioavailability and action. Until now, and although more in vivo and clinical trials are needed, evidence suggests that anthocyanins are promising candidates for the engineering of new pharmaceutical drugs, and can be used as an alternative or as an adjuvant therapy capable to attenuate or prevent the occurrence of many disorders, including diabetes, cancer, and cardiovascular and neurological pathologies. In fact, their use in pharmaceutical products, nutraceuticals, foods, and as food colourants is increasing worldwide.

Author Contributions: Conceptualization, A.C.G., A.F., G.A. and L.R.S.; methodology, A.C.G.; formal analysis, A.C.G.; investigation, A.C.G.; data curation, A.C.G. and A.R.N.; writing, A.C.G.; revising and visualization, A.R.N., G.A., A.F. and L.R.S.; supervision, A.F., G.A. and L.R.S., project administration, G.A. All authors have read and agreed to the published version of the manuscript.

Funding: This research was supported by FCT (Portugal), MCTES (Portugal), EFS (European Social Fund through the Regional Operational Program Centro) and EU (European Union).

Institutional Review Board Statement: Not applicable.

Informed Consent Statement: Not applicable.

Data Availability Statement: Data sharing not applicable.

Acknowledgments: A.C.G. and A.R.N. thank FCT—Foundation for Science and Technology (Lisbon, Portugal) and EFS-European Social Fund through the Regional Operational Program Centro for their PhD fellowship (2020.04947.BD and SFRH/BD/139137/2018, respectively). Figures 2 and 3 were created with ChemDraw Professional 16.0 (CambridgeSoft, Perkin Elmer Inc., Waltham, MA, USA).

Conflicts of Interest: All authors declare no conflict of interest.

\section{References}

1. Mannino, G.; Perrone, A.; Campobenedetto, C.; Schittone, A. Phytochemical profile and antioxidative properties of Plinia trunciflora fruits: A new source of nutraceuticals. Food Chem. 2020, 307, 125515. [CrossRef] [PubMed]

2. Ożarowski, M.; Karpiński, T.M.; Szulc, M.; Wielgus, K.; Kujawski, R.; Wolski, H.; Seremak-Mrozikiewicz, A. Plant phenolics and extracts in animal models of preeclampsia and clinical trials—Review of perspectives for novel therapies. Pharmaceuticals 2021, 14, 269. [CrossRef] [PubMed]

3. Newman, D.J.; Cragg, G.M. Natural products as sources of new drugs over the nearly four decades from 01/1981 to 09/2019. J. Nat. Prod. 2020, 83, 770-803. [CrossRef] [PubMed]

4. Martín, J.; Kuskoski, E.M.; Navas, M.J.; Asuero, A.G. Antioxidant capacity of anthocyanin pigments. In Flavonoids-From Biosynthesis to Human Health; Justino, G.C., Ed.; IntechOpen: London, UK, 2017; pp. 205-255. 
5. Aziz, M.A.; Sarwar, M.S.; Akter, T.; Uddin, M.S.; Xun, S.; Zhu, Y.; Islam, M.S.; Hongjie, Z. Polyphenolic molecules targeting STAT3 pathway for the treatment of cancer. Life Sci. 2021, 268, 118999. [CrossRef] [PubMed]

6. Grosso, G.; Stepaniak, U.; Topor-Madry, R.; Szafraniec, K.; Pajak, A. Estimated dietary intake and major food sources of polyphenols in the Polish arm of the HAPIEE study. Nutrition 2014, 30, 1398-1403. [CrossRef] [PubMed]

7. Alappat, B.; Alappat, J. Anthocyanin pigments: Beyond aesthetics. Molecules 2020, 25, 5500. [CrossRef]

8. Khoo, H.E.; Azlan, A.; Tang, S.T.; Lim, S.M. Anthocyanidins and anthocyanins: Colored pigments as food, pharmaceutical ingredients, and the potential health benefits. Food Nutr. Res. 2017, 61, 1361779. [CrossRef]

9. Bendokas, V.; Skemiene, K.; Trumbeckaite, S.; Passamonti, S.; Borutaite, V.; Liobikas, J. Anthocyanins: From plant pigments to health benefits at mitochondrial level. Crit. Rev. Food Sci. Nutr. 2020, 60, 3352-3365. [CrossRef] [PubMed]

10. Sivamaruthi, B.S.; Kesika, P.; Chaiyasut, C. The influence of supplementation of anthocyanins on obesity-associated comorbidities: A concise review. Foods 2020, 9, 687. [CrossRef] [PubMed]

11. Mertens-Talcott, S.U.; Rios, J.; Jilma-Stohlawetz, P.; Pacheco-Palencia, L.A.; Meibohm, B.; Talcott, S.T.; Derendorf, H. Pharmacokinetics of anthocyanins and antioxidant effects after the consumption of anthocyanin-rich açai juice and pulp (Euterpe oleracea Mart.) in human healthy volunteers. J. Agric. Food Chem. 2008, 56, 7796-7802. [CrossRef]

12. Lynn, A.; Mathew, S.; Moore, C.T.; Russell, J.; Robinson, E.; Soumpasi, V.; Barker, M.E. Effect of a tart cherry juice supplement on arterial stiffness and inflammation in healthy adults: A randomised controlled trial. Plant Foods Hum. Nutr. 2014, 69, 122-127. [CrossRef]

13. Zhu, Y.; Ling, W.; Guo, H.; Song, F.; Ye, Q.; Zou, T.; Li, D.; Zhang, Y.; Li, G.; Xiao, Y.; et al. Anti-inflammatory effect of purified dietary anthocyanin in adults with hypercholesterolemia: A randomized controlled trial. Nutr. Metab. Cardiovasc. Dis. 2013, 23, 843-849. [CrossRef]

14. Kent, K.; Charlton, K.; Roodenrys, S.; Batterham, M.; Potter, J.; Traynor, V.; Gilbert, H.; Morgan, O.; Richards, R. Consumption of anthocyanin-rich cherry juice for 12 weeks improves memory and cognition in older adults with mild-to-moderate dementia. Eur. J. Nutr. 2017, 56, 333-341. [CrossRef]

15. Bowtell, J.L.; Aboo-Bakkar, Z.; Conway, M.; Adlam, A.-L.R.; Fulford, J. Enhanced task related brain activation and resting perfusion in healthy older adults after chronic blueberry supplementation. Appl. Physiol. Nutr. Metab. 2017, 42, 773-779. [CrossRef]

16. Kwon, S.H.; Ahn, I.S.; Kim, S.-O.; Kong, C.S.; Chung, H.Y.; Do, M.S.; Park, K.Y. Anti-obesity and hypolipidemic effects of black soybean anthocyanins. J. Med. Food 2007, 10, 552-556. [CrossRef] [PubMed]

17. Thompson, K.; Hosking, H.; Pederick, W.; Singh, I.; Santhakumar, A.B. The effect of anthocyanin supplementation in modulating platelet function in sedentary population: A randomised, double-blind, placebo-controlled, cross-over trial. Br. J. Nutr. 2017, 118, 368-374. [CrossRef]

18. Shim, S.H.; Kim, J.M.; Choi, C.Y.; Kim, C.Y.; Park, K.H. Ginkgo biloba extract and bilberry anthocyanins improve visual function in patients with normal tension glaucoma. J. Med. Food 2012, 15, 818-823. [CrossRef] [PubMed]

19. Li, L.; Lyall, G.K.; Martinez-blazquez, J.A.; Vallejo, F.; Tomas-barberan, F.A.; Birch, K.M.; Boesch, C. Blood orange juice consumption increases flow-mediated dilation in adults with overweight and obesity: A randomized controlled trial. J. Nutr. 2020, 150, 2287-2294. [CrossRef] [PubMed]

20. Tang, P.; Monica Giusti, M. Metal chelates of petunidin derivatives exhibit enhanced color and stability. Foods 2020, 9, 11-15. [CrossRef] [PubMed]

21. Mladěnka, P.; Říha, M.; Martin, J.; Gorová, B.; Matějíček, A.; Spilková, J. Fruit extracts of 10 varieties of elderberry (Sambucus nigra L.) interact differently with iron and copper. Phytochem. Lett. 2016, 18, 232-238. [CrossRef]

22. Sinopoli, A.; Calogero, G.; Bartolotta, A. Computational aspects of anthocyanidins and anthocyanins: A review. Food Chem. 2019, 297, 124898. [CrossRef]

23. Wu, X.; Beecher, G.R.; Holden, J.M.; Haytowitz, D.B.; Gebhardt, S.E.; Prior, R.L. Concentrations of anthocyanins in common foods in the United States and estimation of normal consumption. J. Agric. Food Chem. 2006, 54, 4069-4075. [CrossRef] [PubMed]

24. Zamora-Ros, R.; Knaze, V.; Luján-Barroso, L.; Slimani, N.; Romieu, I.; Fedirko, V.; Magistris, M.S.; Ericson, U.; Amiano, P.; Trichopoulou, A.; et al. Estimated dietary intakes of flavonols, flavanones and flavones in the European Prospective Investigation into Cancer and Nutrition (EPIC) 24 hour dietary recall cohort. Br. J. Nutr. 2011, 106, 1915-1925. [CrossRef]

25. Rienth, M.; Vigneron, N.; Darriet, P.; Sweetman, C.; Burbidge, C.; Bonghi, C.; Walker, R.P.; Famiani, F.; Castellarin, S.D. Grape berry secondary metabolites and their modulation by abiotic factors in a climate change scenario-A review. Front. Plant Sci. 2021, 12, 1-26. [CrossRef]

26. Šamec, D.; Karalija, E.; Šola, I.; Vujčić Bok, V.; Salopek-Sondi, B. The role of polyphenols in abiotic stress response: The influence of molecular structure. Plants 2021, 10, 118. [CrossRef] [PubMed]

27. Legua, P.; Domenech, A.; Martinez, J.J.; Sánchez-Rodríguez, L.; Hernández, F.; Carbonell-Barrachina, A.A.; Melgarejo, P. Bioactive and volatile compounds in sweet cherry cultivars. J. Food Nutr. Res. 2017, 5, 844-851. [CrossRef]

28. Bresciani, L.; Martini, D.; Mena, P.; Tassotti, M.; Calani, L.; Brigati, G.; Brighenti, F.; Holasek, S.; Malliga, D.E.; Lamprecht, M.; et al. Absorption profile of (poly)phenolic compounds after consumption of three food supplements containing 36 different fruits, vegetables, and berries. Nutrients 2017, 9, 194. [CrossRef] [PubMed]

29. Wang, T.-Y.; Li, Q.; Bi, K.-S. Bioactive flavonoids in medicinal plants: Structure, activity and biological fate. Asian J. Pharm. Sci. 2018, 13, 12-23. [CrossRef] 
30. Landete, J.M. Dietary intake of natural antioxidants: Vitamins and polyphenols. Crit. Rev. Food Sci. Nutr. 2013, 53, 706-721. [CrossRef]

31. Cosme, P.; Rodríguez, A.B.; Espino, J.; Garrido, M. Plant phenolics: Bioavailability as a key determinant of their potential health-promoting applications. Antioxidants 2020, 9, 1263. [CrossRef]

32. Diaconeasa, Z.; Ioana, S.; Xiao, J.; Leopold, N.; Ayvaz, Z.; Danciu, C.; Ayvaz, H.; Sttănilă, A.; Nistor, M.; Socaciu, C. Anthocyanins, vibrant color pigments, and their role in skin cancer prevention. Biomedicines 2020, 8, 336. [CrossRef]

33. Mattioli, R.; Francioso, A.; Mosca, L.; Silva, P. Anthocyanins: A comprehensive review of their chemical properties and health effects on cardiovascular and neurodegenerative diseases. Molecules 2020, 25, 3809. [CrossRef] [PubMed]

34. Ullah, R.; Khan, M.; Shah, S.A.; Saeed, K.; Kim, M.O. Natural antioxidant anthocyanins-A hidden therapeutic candidate in metabolic disorders with major focus in neurodegeneration. Nutrients 2019, 11, 1195. [CrossRef]

35. Ribnickya, D.M.; Roopchand, D.E.; Oren, A.; Grace, M.; Poulev, A.; Lila, M.A.; Havenaar, R.; Raskin, I. Effects of a high fat meal matrix and protein complexation on the bioaccessibility of blueberry anthocyanins using the TNO gastrointestinal model (TIM-1). Food Chem. 2014, 142, 349-357. [CrossRef]

36. Wallace, T.C.; Giusti, M.M. Anthocyanins. Adv. Nutr. 2015, 6, 620-622. [CrossRef] [PubMed]

37. Prior, R.L.; Wu, X. Anthocyanins: Structural characteristics that result in unique metabolic patterns and biological activities. Free Radic. Res. 2006, 40, 1014-1028. [CrossRef] [PubMed]

38. Tena, N.; Martín, J.; Asuero, A.G. State of the art of anthocyanins: Antioxidant activity, sources, bioavailability, and therapeutic effect in human health. Antioxidants 2020, 9, 451. [CrossRef] [PubMed]

39. White, B.L.; Howard, L.R.; Prior, R.L. Proximate and polyphenolic characterization of cranberry pomace. J. Agric. Food Chem. 2010, 58, 4030-4036. [CrossRef] [PubMed]

40. Gonçalves, A.C.; Campos, G.; Alves, G.; Garcia-Viguera, C.; Moreno, D.A.; Silva, L.R. Physical and phytochemical composition of 23 Portuguese sweet cherries as conditioned by variety (or genotype). Food Chem. 2021, 335, 127637. [CrossRef] [PubMed]

41. Pojer, E.; Mattivi, F.; Johnson, D.; Stockley, C.S. The case for anthocyanin consumption to promote human health: A review. Compr. Rev. Food Sci. Food Saf. 2013, 12, 483-508. [CrossRef] [PubMed]

42. Escobar-Cévoli, R.; Castro-Espín, C.; Béraud, V.; Buckland, G.; Zamora-Ros, R. An overview of global flavonoid intake and its food sources. In Flavonoids_From Biosynthesis to Human Health; Justino, G.C., Ed.; InTech: London, UK, 2017 ; pp. 371-391.

43. Igwe, E.O.; Charlton, K.E.; Probst, Y.C. Usual dietary anthocyanin intake, sources and their association with blood pressure in a representative sample of Australian adults. J. Hum. Nutr. Diet. 2019, 32, 578-590. [CrossRef]

44. Chinese Nutrition Society. Chinese DRIs Handbook; Standards Press of China: Beijing, China, 2013.

45. Kim, K.; Vance, T.M.; Chun, O.K. Estimated intake and major food sources of flavonoids among US adults: Changes between 1999-2002 and 2007-2010 in NHANES. Eur. J. Nutr. 2016, 55, 833-843. [CrossRef]

46. Wu, X.; Prior, R.L. Identification and characterization of anthocyanins by HPLC-ESI-MS/MS in common foods in the United States: Fruits and berries. J. Agric. Food Chem. 2005, 53, 2589-2599. [CrossRef]

47. Frond, A.D.; Iuhas, C.I.; Stirbu, I.; Leopold, L.; Socaci, S.; Andreea, S.; Ayvaz, H.; Andreea, S.; Mihai, S.; Zorita, D.; et al. Phytochemical characterization of five edible purple-reddish vegetables: Anthocyanins, flavonoids, and phenolic acid derivatives. Molecules 2019, 24, 1536. [CrossRef] [PubMed]

48. Kharadze, M.; Japaridze, I.; Kalandia, A.; Vanidze, M. Anthocyanins and antioxidant activity of red wines made from endemic grape varieties. Ann. Agrar. Sci. 2018, 16, 181-184. [CrossRef]

49. Horincar, G.; Enachi, E.; Bolea, C.; Râpeanu, G.; Aprodu, I. Value-added lager beer enriched with eggplant (Solanum melongena L.) peel extract. Molecules 2020, 25, 731. [CrossRef]

50. Zambrano-Moreno, E.L.; Chávez-Jáuregui, R.N.; Plaza, M.d.L.; Wessel-Beaver, L. Phenolic content and antioxidant capacity in organically and conventionally grown eggplant (Solanum melongena) fruits following thermal processing. Food Sci. Technol. 2015, 35, 414-420. [CrossRef]

51. de Rosso, V.V.; Hillebrand, S.; Montilla, E.C.; Bobbio, F.O.; Winterhalter, P.; Mercadante, A.Z. Determination of anthocyanins from acerola (Malpighia emarginata DC.) and açai (Euterpe oleracea Mart.) by HPLC-PDA-MS/MS. J. Food Compos. Anal. 2008, 21, 291-299. [CrossRef]

52. Polat, M.; Okatan, V.; Güclü, S.F.; Çolak, A.M. Determination of some chemical characteristics and total antioxidant capacity in apple varieties grown in Posof/Ardahan region. Int. J. Agric. Environ. Food Sci. 2018, 2, 131-134. [CrossRef]

53. Wang, S.Y.; HsinShan, L. Antioxidant activity in fruits and leaves of blackberry, raspberry, and strawberry varies with cultivar and developmental stage. J. Agric. Food Chem. 2000, 48, 140-146. [CrossRef] [PubMed]

54. Fan-Chiang, H.-J.; Wrolstad, R.E. Anthocyanin pigment composition of blackberries. JFS C Food Chem. Toxicol. 2005, 70, 198-202. [CrossRef]

55. Jakobek, L.; Seruga, M.; Novak, I.; Medvidovic-Kosanovic, M. Flavonols, phenolic acids and antioxidant activity of some red fruits. Dtsch. Leb. 2007, 103, 369-378.

56. Esposito, D.; Damsud, T.; Wilson, M.; Grace, M.H.; Strauch, R.; Li, X.; Lila, M.A.; Komarnytsky, S. Black currant anthocyanins attenuate weight gain and improve glucose metabolism in diet-induced obese mice with intact, but not disrupted, gut microbiome. J. Agric. Food Chem. 2015, 63, 6172-6180. [CrossRef] [PubMed]

57. Mazza, G.; Kay, C.D.; Cottrell, T.; Holub, B.J. Absorption of anthocyanins from blueberries and serum antioxidant status in human subjects. J. Agric. Food Chem. 2002, 50, 45-48. [CrossRef] [PubMed] 
58. Zielińska, A.; Siudem, P.; Paradowska, K.; Gralec, M.; Kaźmierski, S.; Wawer, I. Aronia melanocarpa fruits as a rich dietary source of chlorogenic acids and anthocyanins: 1H-NMR, HPLC-DAD, and chemometric studies. Molecules 2020, $25,3234$. [CrossRef] [PubMed]

59. Jasutiene, L.; Cesonienè, I.; Sarkinas, A. Phenolics and anthocyanins in berries of European cranberry and their antimicrobial activity. Medicina 2009, 45, 992-999.

60. Duymuş, H.G.; Göger, F.; Başer, K.H.C. In vitro antioxidant properties and anthocyanin compositions of elderberry extracts. Food Chem. 2014, 155, 112-119. [CrossRef]

61. Solomon, A.; Golubowicz, S.; Yablowicz, Z.; Grossman, S.; Bergman, M.; Gottlieb, H.E.; Altman, A.; Kerem, Z.; Flaishman, M.A. Antioxidant activities and anthocyanin content of fresh fruits of common fig (Ficus carica L.). J. Agric. Food Chem. 2006, 54, 7717-7723. [CrossRef]

62. Kamiloglu, S.; Capanoglu, E. Polyphenol content in figs (Ficus carica L.): Effect of sun-drying. Int. J. Food Prop. 2015, 18, 521-535. [CrossRef]

63. Silva, L.R.; Queiroz, M. Bioactive compounds of red grapes from Dão region (Portugal): Evaluation of phenolic and organic profile. Asian Pac. J. Trop. Biomed. 2016, 6, 315-321. [CrossRef]

64. Kallithraka, S.; Aliaj, L.; Makris, D.P.; Kefalas, P. Anthocyanin profiles of major red grape (Vitis vinifera L.) varieties cultivated in Greece and their relationship with in vitro antioxidant characteristics. Int. J. Food Sci. Technol. 2009, 44, 2385-2393. [CrossRef]

65. Khattab, R.; Brooks, M.S.-L.; Ghanem, A. Phenolic analyses of haskap berries (Lonicera caerulea L.): Spectrophotometry versus high performance liquid chromatography. Int. J. Food Prop. 2016, 19, 1708-1725. [CrossRef]

66. Celli, G.B.; Ghanem, A.; Brooks, M.S.L. Optimization of ultrasound-assisted extraction of anthocyanins from haskap berries (Lonicera caerulea L.) using Response Surface Methodology. Ultrason. Sonochem. 2015, 27, 449-455. [CrossRef] [PubMed]

67. Cantín, C.M.; Moreno, M.A.; Gogorcena, Y. Evaluation of the antioxidant capacity, phenolic compounds, and vitamin C content of different peach and nectarine [Prunus persica (L.) batsch] breeding progenies. J. Agric. Food Chem. 2009, 57, 4586-4592. [CrossRef]

68. Usenik, V.; Štampar, F.; Veberič, R. Anthocyanins and fruit colour in plums (Prunus domestica L.) during ripening. Food Chem. 2009, 114, 529-534. [CrossRef]

69. Passafiume, R.; Perrone, A.; Sortino, G.; Gianguzzi, G.; Saletta, F.; Gentile, C.; Farina, V. Chemical-physical characteristics, polyphenolic content and total antioxidant activity of three Italian-grown pomegranate cultivars. NFS J. 2019, 16, 9-14. [CrossRef]

70. Zhu, F.; Yuan, Z.; Zhao, X.; Yin, Y.; Feng, L. Composition and contents of anthocyanins in different pomegranate cultivars. Acta Hortic. 2015, 1089, 35-41.

71. Mihaylova, D.; Popova, A.; Desseva, I.; Petkova, N.; Stoyanova, M.; Vrancheva, R.; Slavov, A.; Slavchev, A.; Lante, A. Comparative study of early- and mid-ripening peach (Prunus persica L.) varieties: Biological activity, macro-, and micro- nutrient profile. Foods 2021, 10, 164. [CrossRef]

72. Bento, C.; Gonçalves, A.C.; Silva, B.; Silva, L.R. Assessing the phenolic profile, antioxidant, antidiabetic and protective effects against oxidative damage in human erythrocytes of peaches from Fundão. J. Funct. Foods 2018, 43, 224-233. [CrossRef]

73. Wiczkowski, W.; Szawara-Nowak, D.; Topolska, J. Red cabbage anthocyanins: Profile, isolation, identification, and antioxidant activity. Food Res. Int. 2013, 51, 303-309. [CrossRef]

74. Ahmadiani, N.; Robbins, R.J.; Collins, T.M.; Giusti, M.M. Anthocyanins contents, profiles, and color characteristics of red cabbage extracts from different cultivars and maturity stages. J. Agric. Food Chem. 2014, 62, 7524-7531. [CrossRef]

75. Jara-Palacios, M.J.; Santisteban, A.; Gordillo, B.; Hernanz, D.; Heredia, F.J.; Escudero-Gilete, M.L. Comparative study of red berry pomaces (blueberry, red raspberry, red currant and blackberry) as source of antioxidants and pigments. Eur. Food Res. Technol. 2019, 245, 1-9. [CrossRef]

76. Galvis Sánchez, A.C.; Gil-Izquierdo, A.; Gil, M.I. Comparative study of six pear cultivars in terms of their phenolic and vitamin C contents and antioxidant capacity. J. Sci. Food Agric. 2003, 83, 995-1003. [CrossRef]

77. Ludwig, I.A.; Mena, P.; Calani, L.; Borges, G.; Pereira-Caro, G.; Bresciani, L.; Del Rio, D.; Lean, M.E.J.; Crozier, A. New insights into the bioavailability of red raspberry anthocyanins and ellagitannins. Free Radic. Biol. Med. 2015, 89, 758-769. [CrossRef] [PubMed]

78. Wang, H.; Nair, M.G.; Strasburg, G.M.; Booren, M.; Gray, I.; Dewitt, D.L. Cyclooxygenase active bioflavonoids from Balaton tart cherry and their structure activity relationships. Phytomedicine 2000, 7, 15-19. [CrossRef]

79. Silva, F.L.; Escribano-Bailón, M.T.; Pérez Alonso, J.J.; Rivas-Gonzalo, J.C.; Santos-Buelga, C. Anthocyanin pigments in strawberry. LWT-Food Sci. Technol. 2007, 40, 374-382. [CrossRef]

80. Gonçalves, A.C.; Bento, C.; Silva, B.M.; Silva, L.R. Sweet cherries from Fundão possess antidiabetic potential and protect human erythrocytes against oxidative damage. Food Res. Int. 2017, 95, 91-100. [CrossRef] [PubMed]

81. Martini, S.; Conte, A.; Tagliazucchi, D. Phenolic compounds profile and antioxidant properties of six sweet cherry (Prunus avium) cultivars. Food Res. Int. 2017, 97, 15-26. [CrossRef]

82. Diep, T.; Pook, C.; Yoo, M. Phenolic and anthocyanin compounds and antioxidant activity of Tamarillo (Solanum betaceum Cav.). Antioxidants 2020, 9, 169. [CrossRef]

83. Cao, J.; Jiang, Q.; Lin, J.; Li, X.; Sun, C.; Chen, K. Physicochemical characterisation of four cherry species (Prunus spp.) grown in China. Food Chem. 2015, 173, 855-863. [CrossRef]

84. Borghesi, E.; González-Miret, M.L.; Escudero-Gilete, M.L.; Malorgio, F.; Heredia, F.J.; Meléndez-Martínez, A.J. Effects of salinity stress on carotenoids, anthocyanins, and color of diverse tomato genotypes. J. Agric. Food Chem. 2011, 59, 11676-11682. [CrossRef] 
85. Blando, F.; Berland, H.; Maiorano, G.; Durante, M.; Mazzucato, A.; Picarella, M.E.; Nicoletti, I.; Gerardi, C.; Mita, G.; Andersen, Ø.M. Nutraceutical characterization of anthocyanin-rich fruits produced by "Sun Black" tomato line. Front. Nutr. 2019, 6, 133. [CrossRef] [PubMed]

86. Kammerer, D.; Carle, R.; Schieber, A. Quantification of anthocyanins in black carrot extracts (Daucus carota ssp. sativus var. atrorubens Alef.) and evaluation of their color properties. Eur. Food Res. Technol. 2004, 219, 479-486. [CrossRef]

87. Shi-Lin, Z.; Peng, D.; Yu-Chao, X.; Jian-Jun, W. Quantification and analysis of anthocyanin and flavonoids compositions, and antioxidant activities in onions with three different colors. J. Integr. Agric. 2016, 15, 2175-2181.

88. Legua, P.; Melgarejo, P.; Martínez, J.J.; Martínez, R.; Hernández, F. Evaluation of Spanish pomegranate juices: Organic acids, sugars, and anthocyanins. Int. J. Food Prop. 2012, 15, 481-494. [CrossRef]

89. Lapidot, T.; Harel, S.; Granit, R.; Kanner, J. Bioavailability of red wine anthocyanins as detected in human urine. J. Agric. Food Chem. 1998, 46, 4297-4302. [CrossRef]

90. Kirakosyan, A.; Seymour, E.M.; Llanes, D.E.U.; Kaufman, P.B.; Bolling, S.F. Chemical profile and antioxidant capacities of tart cherry products. Food Chem. 2009, 115, 20-25. [CrossRef]

91. Oliveira, H.; Roma-Rodrigues, C.; Santos, A.; Veigas, B.; Brás, N.; Faria, A.; Calhau, C.; De Freitas, V.; Baptista, P.V.; Mateus, N.; et al. GLUT1 and GLUT3 involvement in anthocyanin gastric transport- Nanobased targeted approach. Sci. Rep. 2019, 789, 1-14. [CrossRef]

92. European Food Safety Authority. Scientific opinion on the re-evaluation of anthocyanins (E 163) as a food additive. EFSA J. 2013, 11,3145 .

93. Matsumoto, H.; Inaba, H.; Kishi, M.; Tominaga, S.; Hirayama, M.; Tsuda, T. Orally administered delphinidin 3-rutinoside and cyanidin 3-rutinoside are directly absorbed in rats and humans and appear in the blood as the intact forms. J. Agric. Food Chem. 2001, 49, 1546-1551. [CrossRef]

94. Cao, G.; Muccitelli, H.U.; Sánchez-Moreno, C.; Prior, R.L. Anthocyanins are absorbed in glycated forms in elderly women: A pharmacokinetic study. Am. J. Clin. Nutr. 2001, 73, 920-926. [CrossRef]

95. Sandhu, A.K.; Huang, Y.; Xiao, D.; Park, E.; Edirisinghe, I.; Burton-Freeman, B. Pharmacokinetic characterization and bioavailability of strawberry anthocyanins relative to meal intake. J. Agric. Food Chem. 2016, 64, 4891-4899. [CrossRef]

96. Nielsen, I.L.F.; Dragsted, L.O.; Ravn-haren, G.; Freese, R.; Rasmussen, S.E. Absorption and excretion of black currant anthocyanins in humans and watanabe heritable hyperlipidemic rabbits. J. Agric. Food Chem. 2003, 51, 2813-2820. [CrossRef]

97. Bitsch, R.; Netzel, M.; Frank, T.; Strass, G.; Bitsch, I. Bioavailability and biokinetics of anthocyanins from red grape juice and red wine. J. Biomed. Biotechnol. 2004, 2004, 293-298. [CrossRef]

98. Milbury, P.E.; Vita, J.A.; Blumberg, J.B. Anthocyanins are bioavailable in humans following an acute dose of cranberry juice. J. Nutr. 2010, 140, 1099-1104. [CrossRef] [PubMed]

99. Keane, K.M.; Bell, P.G.; Lodge, J.K.; Constantinou, C.L.; Jenkinson, S.E.; Bass, R.; Howatson, G. Phytochemical uptake following human consumption of Montmorency tart cherry (L. Prunus cerasus) and influence of phenolic acids on vascular smooth muscle cells in vitro. Eur. J. Nutr. 2016, 55, 1695-1705. [CrossRef]

100. Kuntz, S.; Rudloff, S.; Asseburg, H.; Borsch, C.; Fröhling, B.; Unger, F.; Dold, S.; Spengler, B.; Römpp, A.; Kunz, C. Uptake and bioavailability of anthocyanins and phenolic acids from grape/blueberry juice and smoothie in vitro and in vivo. Br. J. Nutr. 2015, 113, 1044-1055. [CrossRef] [PubMed]

101. Giordano, L.; Coletta, W.; Tamburrelli, C.; D’Imperio, M.; Crescente, M.; Silvestri, C.; Rapisarda, P.; Reforgiato Recupero, G.; De Curtis, A.; Iacoviello, L.; et al. Four-week ingestion of blood orange juice results in measurable anthocyanin urinary levels but does not affect cellular markers related to cardiovascular risk: A randomized cross-over study in healthy volunteers. Eur. J. Nutr. 2012, 51, 541-548. [CrossRef] [PubMed]

102. Wiczkowski, W.; Romaszko, E.; Piskula, M.K. Bioavailability of cyanidin glycosides from natural chokeberry (Aronia melanocarpa) juice with dietary-relevant dose of anthocyanins in humans. J. Agric. Food Chem. 2010, 58, 12130-12136. [CrossRef] [PubMed]

103. McGhie, T.K.; Ainge, G.D.; Barnett, L.E.; Cooney, J.M.; Jensen, D.J. Anthocyanin glycosides from berry fruit are absorbed and excreted unmetabolized by both humans and rats. J. Agric. Food Chem. 2003, 51, 4539-4548. [CrossRef]

104. Morazzoni, P.; Bombardelli, E. Vaccinium myrtillus L. Fitoterapia 1996, 67, 3-29.

105. He, J.; Giusti, M.M. Anthocyanins: Natural colorants with health-promoting properties. Annu. Rev. Food Sci. Technol. 2010, 1, 163-187. [CrossRef]

106. Oliveira, H.; Perez-Gregório, R.; Freitas, V.; Mateus, N.; Fernandes, I. Comparison of the in vitro gastrointestinal bioavailability of acylated and non-acylated anthocyanins: Purple-fleshed sweet potato vs red wine. Food Chem. 2018, 276, 410-418. [CrossRef] [PubMed]

107. Passamonti, S.; Vrhovsek, U.; Mattivi, F. The interaction of anthocyanins with bilitranslocase. Biochem. Biophys. Res. Commun. 2002, 296, 631-636. [CrossRef]

108. Velderrain-Rodríguez, G.R.; Palafox-Carlos, H.; Wall-Medrano, A.; Ayala-Zavala, J.F.; Chen, C.Y.O.; Robles-Sánchez, M.; Astiazaran-García, H.; Alvarez-Parrilla, E.; González-Aguilar, G.A. Phenolic compounds: Their journey after intake. Food Funct. 2014, 5, 189-197. [CrossRef]

109. Han, F.; Oliveira, H.; Brás, N.F.; Fernandes, I.; Cruz, L.; de Freitas, V.; Mateus, N. In vitro gastrointestinal absorption of red wine anthocyanins-Impact of structural complexity and phase II metabolization. Food Chem. 2020, 317, 126398. [CrossRef] [PubMed] 
110. Ramos, P.; Herrera, R.; Moya-león, M.A. Anthocyanins: Food sources and benefits to consumer's health. In Handbook of Anthocyanins; Warner, L.M., Ed.; Nova Science Publishers, Inc.: New York, NY, USA, 2014; pp. 363-384.

111. Eker, M.E.; Aaby, K.; Budic-Leto, I.; Brncic, S.R.; El, S.N.; Karakaya, S.; Simsek, S.; Manach, C.; Wiczkowski, W.; De Pascual-Teresa, S. A review of factors affecting anthocyanin bioavailability: Possible implications for the inter-individual variability. Foods 2020, 9, 2. [CrossRef] [PubMed]

112. Mueller, D.; Jung, K.; Winter, M.; Rogoll, D.; Melcher, R.; Kulozik, U.; Schwarz, K.; Richling, E. Encapsulation of anthocyanins from bilberries-Effects on bioavailability and intestinal accessibility in humans. Food Chem. 2018, 248, 217-224. [CrossRef] [PubMed]

113. Rodriguez-Mateos, A.; Vauzour, D.; Krueger, C.G.; Shanmuganayagam, D.; Reed, J.; Calani, L.; Mena, P.; Del Rio, D.; Crozier, A. Bioavailability, bioactivity and impact on health of dietary flavonoids and related compounds: An update. Arch. Toxicol. 2014, 88, 1803-1853. [CrossRef] [PubMed]

114. Norberto, S.; Silva, S.; Meireles, M.; Faria, A.; Pintado, M.; Calhau, C. Blueberry anthocyanins in health promotion: A metabolic overview. J. Funct. Foods 2013, 5, 1518-1528. [CrossRef]

115. Azzini, E.; Bugianesi, R.; Romano, F.; Di Venere, D.; Miccadei, S.; Durazzo, A.; Foddai, M.S.; Catasta, G.; Linsalata, V.; Maiani, G. Absorption and metabolism of bioactive molecules after oral consumption of cooked edible heads of Cynara scolymus L. (cultivar Violetto di Provenza) in human subjects: A pilot study. Br. J. Nutr. 2007, 97, 963-969. [CrossRef]

116. Martini, S.; Conte, A.; Tagliazucchi, D. Bioactivity and cell metabolism of in vitro digested sweet cherry (Prunus avium) phenolic compounds. Int. J. Food Sci. Nutr. 2018, 70, 335-348. [CrossRef]

117. Dharmawansa, K.V.S.; Hoskin, D.W.; Rupasinghe, H.P. Chemopreventive effect of dietary anthocyanins against gastrointestinal cancers: A review of recent advances and perspectives. Int. J. Mol. Sci. 2020, 21, 6555. [CrossRef] [PubMed]

118. Mueller, D.; Jung, K.; Winter, M.; Rogoll, D.; Melcher, R.; Richling, E. Human intervention study to investigate the intestinal accessibility and bioavailability of anthocyanins from bilberries. Food Chem. 2017, 231, 275-286. [CrossRef] [PubMed]

119. Lin, S.; Wang, Z.; Lam, K.L.; Zeng, S.; Tan, B.K.; Hu, J. Role of intestinal microecology in the regulation of energy metabolism by dietary polyphenols and their metabolites. Food Nutr. Res. 2019, 63, 1-12. [CrossRef] [PubMed]

120. Yang, L.; Ling, W.; Yang, Y.; Chen, Y.; Tian, Z.; Du, Z.; Chen, J.; Xie, Y.; Liu, Z.; Yang, L. Role of purified anthocyanins in improving cardiometabolic risk factors in chinese men and women with prediabetes or early untreated diabetes-A randomized controlled trial. Nutrients 2017, 9, 1104. [CrossRef]

121. Kim, M.J.; Rehman, S.U.; Amin, F.U.; Kim, M.O. Enhanced neuroprotection of anthocyanin-loaded PEG-gold nanoparticles against A $\beta 1-42$-induced neuroinflammation and neurodegeneration via the NF-KB /JNK/GSK3 $\beta$ signaling pathway. Nanomed. Nanotechnol. Biol. Med. 2017, 13, 2533-2544. [CrossRef]

122. Amin, F.U.; Shah, S.A.; Badshah, H.; Khan, M.; Kim, M.O. Anthocyanins encapsulated by PLGA@PEG nanoparticles potentially improved its free radical scavenging capabilities via p38/JNK pathway against A $\beta 1-42$-induced oxidative stress. J. Nanobiotechnol. 2017, 15, 12. [CrossRef]

123. Thibado, S.; Thornthwaite, J.; Ballard, T.; Goodman, B. Anticancer effects of bilberry anthocyanins compared with NutraNanoSphere encapsulated bilberry anthocyanins. Mol. Clin. Oncol. 2017, 8, 330-335. [CrossRef]

124. Ma, Y.; Ding, S.; Fei, Y.; Liu, G.; Jang, H.; Fang, J. Antimicrobial activity of anthocyanins and catechins against foodborne pathogens Escherichia coli and Salmonella. Food Control 2019, 106, 106712. [CrossRef]

125. Sun, X.; Zhou, T.; Wei, C.; Lan, W.; Zhao, Y.; Pan, Y.; Wu, V.C.H. Antibacterial effect and mechanism of anthocyanin rich Chinese wild blueberry extract on various foodborne pathogens. Food Control 2018, 94, 155-161. [CrossRef]

126. Kim, S.H.; Park, M.; Woo, H.; Tharmalingam, N.; Lee, G.; Rhee, K.J.; Eom, Y. Bin; Han, S.I.; Seo, W.D.; Kim, J.B. Inhibitory effects of anthocyanins on secretion of Helicobacter pylori CagA and VacA toxins. Int. J. Med. Sci. 2012, 9, 838-842. [CrossRef] [PubMed]

127. Bendokas, V.; Šarkinas, A.; Jasinauskienë, D.; Anisimovienë, N.; Morkûnaitë-Haimi, Š.; Stanys, V.; Šikšnianas, T. Antimicrobial activity of berries extracts of four Ribes species, their phenolic content and anthocyanin composition. Folia Hortic. 2018, 30, 249-257. [CrossRef]

128. Chen, H.; Yu, W.; Chen, G.; Meng, S.; Xiang, Z.; He, N. Antinociceptive and antibacterial properties of anthocyanins and flavonols from fruits of black and non-black mulberries. Molecules 2018, 23, 4. [CrossRef]

129. Majiene, D.; Liobikas, J.; Trumbeckaite, S.; Kopustinskiene, D.M.; Bendokas, V.; Sasnauskas, A.; Šikšnianas, T.; Liegiute, S.; Anisimoviene, N. Antioxidative and antimicrobial activity of anthocyanin-rich extracts from fruits of blackcurrant and cherry. Acta Hortic. 2014, 1040, 173-178. [CrossRef]

130. Silva, S.; Costa, E.M.; Mendes, M.; Morais, R.M.; Calhau, C.; Pintado, M.M. Antimicrobial, antiadhesive and antibiofilm activity of an ethanolic, anthocyanin-rich blueberry extract purified by solid phase extraction. J. Appl. Microbiol. 2016, 121, 693-703. [CrossRef]

131. Carvalho, F.B.; Gutierres, J.M.; Bohnert, C.; Zago, A.M.; Abdalla, F.H.; Vieira, J.M.; Palma, H.E.; Oliveira, S.M.; Spanevello, R.M.; Duarte, M.M.; et al. Anthocyanins suppress the secretion of proinflammatory mediators and oxidative stress, and restore ion pump activities in demyelination. J. Nutr. Biochem. 2015, 26, 378-390. [CrossRef]

132. Rashid, K.; Wachira, F.N.; Nyariki, J.N.; Isaac, A.O. Kenyan purple tea anthocyanins and coenzyme-Q10 ameliorate post treatment reactive encephalopathy associated with cerebral human African trypanosomiasis in murine model. Parasitol. Int. 2014, 63, 417-426. [CrossRef] 
133. Yoon, B.I.; Bae, W.J.; Choi, Y.S.; Kim, S.J.; Ha, U.S.; Hong, S.H.; Sohn, D.W.; Kim, S.W. Anti-inflammatory and antimicrobial effects of anthocyanin extracted from black soybean on chronic bacterial prostatitis rat model. Chin. J. Integr. Med. 2018, 24, 621-626. [CrossRef]

134. Gonçalves, A.C.; Rodrigues, M.; Santos, A.O.; Alves, G.; Silva, L.R. Antioxidant status, antidiabetic properties and effects on Caco-2 cells of colored and non-colored enriched extracts of sweet cherry fruits. Nutrients 2018, 10, 1688. [CrossRef]

135. Kähkönen, M.P.; Heinonen, M. Antioxidant activity of anthocyanins and their aglycons. J. Agric. Food Chem. 2003, 51, 628-633. [CrossRef]

136. Sadeer, N.B.; Montesano, D.; Albrizio, S.; Zengin, G.; Mahomoodally, M.F. The versatility of antioxidant assays in food science and safety-Chemistry, applications, strengths, and limitations. Antioxidants 2020, 9, 709. [CrossRef]

137. Rahman, M.M.; Ichiyanagi, T.; Komiyama, T.; Hatano, Y.; Konishi, T. Superoxide radical- and peroxynitrite-scavenging activity of anthocyanins; structure-activity relationship and their synergism. Free Radic. Res. 2006, 40, 993-1002. [CrossRef]

138. Tarozzi, A.; Marchesi, A.; Hrelia, S.; Angeloni, C.; Andrisano, V.; Fiori, J.; Cantelli-Forti, G.; Hrelia, P. Protective effects of Cyanidin-3-O- $\beta$-glucopyranoside against UVA-Induced Oxidative Stress in Human Keratinocytes. Photochem. Photobiol. 2005, 81, 623-629. [CrossRef]

139. Heinonen, I.M.; Meyer, A.S.; Frankel, E.N. Antioxidant activity of berry phenolics on human low-density lipoprotein and liposome oxidation. J. Agric. Food Chem. 1998, 46, 4107-4112. [CrossRef]

140. Elisia, I.; Hu, C.; Popovich, D.G.; Kitts, D.D. Antioxidant assessment of an anthocyanin-enriched blackberry extract. Food Chem. 2007, 101, 1052-1058. [CrossRef]

141. Bowen-Forbes, C.S.; Zhang, Y.; Nair, M.G. Anthocyanin content, antioxidant, anti-inflammatory and anticancer properties of blackberry and raspberry fruits. J. Food Compos. Anal. 2010, 23, 554-560. [CrossRef]

142. Afaq, F.; Syed, D.N.; Malik, A.; Hadi, N.; Sarfaraz, S.; Kweon, M.H.; Khan, N.; Zaid, M.A.; Mukhtar, H. Delphinidin, an anthocyanidin in pigmented fruits and vegetables, protects human HaCaT keratinocytes and mouse skin against UVB-mediated oxidative stress and apoptosis. J. Investig. Dermatol. 2007, 127, 222-232. [CrossRef]

143. Hassimotto, N.M.A.; Lajolo, F.M. Antioxidant status in rats after long-term intake of anthocyanins and ellagitannins from blackberries. J. Sci. Food Agric. 2011, 91, 523-531. [CrossRef] [PubMed]

144. Khoo, H.E.; Azlan, A.; Nurulhuda, M.H.; Ismail, A.; Abas, F.; Hamid, M.; Roowi, S. Antioxidative and cardioprotective properties of anthocyanins from defatted Dabai extracts. Evid. Based Complement. Altern. Med. 2013, 2013, 434057. [CrossRef]

145. Azzini, E.; Intorre, F.; Vitaglione, P.; Napolitano, A.; Foddai, M.S.; Durazzo, A.; Fumagalli, A.; Catasta, G.; Rossi, L.; Venneria, E.; et al. Absorption of strawberry phytochemicals and antioxidant status changes in humans. J. Berry Res. 2010, 1, 81-89. [CrossRef]

146. Kuntz, S.; Kunz, C.; Herrmann, J.; Borsch, C.H.; Abel, G.; Fröhling, B.; Dietrich, H.; Rudloff, S. Anthocyanins from fruit juices improve the antioxidant status of healthy young female volunteers without affecting anti-inflammatory parameters: Results from the randomised, double-blind, placebo-controlled, cross-over ANTHONIA (ANTHOcyanins in Nutrition. Br. J. Nutr. 2014, 112, 925-936. [CrossRef]

147. Del Bo', C.; Riso, P.; Campolo, J.; Møller, P.; Loft, S.; Klimis-Zacas, D.; Brambilla, A.; Rizzolo, A.; Porrini, M. A single portion of blueberry (Vaccinium corymbosum $\mathrm{L}$ ) improves protection against DNA damage but not vascular function in healthy male volunteers. Nutr. Res. 2013, 33, 220-227. [CrossRef] [PubMed]

148. Bialasiewicz, P.; Prymont-Przyminska, A.; Zwolinska, A.; Sarniak, A.; Wlodarczyk, A.; Krol, M.; Glusac, J.; Nowak, P.; Markowski, J.; Rutkowski, K.P.; et al. Addition of strawberries to the usual diet decreases resting chemiluminescence of fasting blood in healthy subjects-possible health-promoting effect of these fruits Consumption. J. Am. Coll. Nutr. 2013, 4, 274-287. [CrossRef]

149. Hutchison, A.T.; Flieller, E.B.; Dillon, K.J.; Leverett, B.D. Black currant nectar reduces muscle damage and inflammation following a bout of high-intensity eccentric contractions. J. Diet. Suppl. 2014, 13, 1-15. [CrossRef] [PubMed]

150. Howatson, G.; McHugh, M.P.; Hill, J.A.; Brouner, J.; Jewell, A.P.; Van Someren, K.A.; Shave, R.E.; Howatson, S.A. Influence of tart cherry juice on indices of recovery following marathon running. Scand. J. Med. Sci. Sport. 2010, 20, 843-852. [CrossRef] [PubMed]

151. Hurst, R.D.; Lyall, K.A.; Wells, R.W.; Sawyer, G.M.; Lomiwes, D.; Ngametua, N.; Hurst, S.M. Daily consumption of an anthocyaninrich extract made from New Zealand blackcurrants for 5 weeks supports exercise recovery through the management of oxidative stress and inflammation: A randomized placebo controlled pilot study. Front. Nutr. 2020, 7, 1-15. [CrossRef] [PubMed]

152. Jiang, T.; Zhou, J.; Liu, W.; Tao, W.; He, J.; Jin, W.; Guo, H.; Yang, N.; Li, Y. The anti-inflammatory potential of proteinbound anthocyanin compounds from purple sweet potato in LPS-induced RAW264.7 macrophages. Food Res. Int. 2020, 137, 109647. [CrossRef]

153. Fernandez-Panchon, M.S.; Villano, D.; Troncoso, A.M.; Garcia-Parrilla, M.C. Antioxidant activity of phenolic compounds: From in vitro results to in vivo evidence. Crit. Rev. Food Sci. Nutr. 2008, 48, 649-671. [CrossRef] [PubMed]

154. Szymanowska, U.; Baraniak, B. Antioxidant and potentially anti-inflammatory activity of anthocyanin fractions from pomace obtained from enzymatically treated raspberries. Antioxidants 2019, 8, 299. [CrossRef]

155. Li, L.; Wang, L.; Wu, Z.; Yao, L.; Wu, Y.; Huang, L.; Liu, K.; Zhou, X.; Gou, D. Anthocyanin-rich fractions from red raspberries attenuate inflammation in both RAW264.7 macrophages and a mouse model of colitis. Sci. Rep. 2014, 4, 6234. [CrossRef] [PubMed]

156. Van de Velde, F.; Esposito, D.; Grace, M.H.; Pirovani, M.E.; Lila, M.A. Anti-inflammatory and wound healing properties of polyphenolic extracts from strawberry and blackberry fruits. Food Res. Int. 2019, 121, 453-462. [CrossRef] [PubMed]

157. Jang, B.K.; Lee, J.W.; Choi, H.; Yim, S.V. Aronia melanocarpa fruit bioactive fraction attenuates lps-induced inflammatory response in human bronchial epithelial cells. Antioxidants 2020, 9, 816. [CrossRef] [PubMed] 
158. Pereira, S.R.; Pereira, R.; Figueiredo, I.; Freitas, V.; Dinis, T.C.P.; Almeida, L.M. Comparison of anti-inflammatory activities of an anthocyanin-rich fraction from Portuguese blueberries (Vaccinium corymbosum L.) and 5-aminosalicylic acid in a TNBS-induced colitis rat model. PLoS ONE 2017, 12, e0174116. [CrossRef] [PubMed]

159. Tall, J.M.; Seeram, N.P.; Zhao, C.; Nair, M.G.; Meyer, R.A.; Raja, S.N. Tart cherry anthocyanins suppress inflammation-induced pain behavior in rat. Behav. Brain Res. 2004, 153, 181-188. [CrossRef]

160. Palungwachira, P.; Tancharoen, S.; Phruksaniyom, C.; Klungsaeng, S.; Srichan, R.; Kikuchi, K.; Nararatwanchai, T. Antioxidant and anti-inflammatory properties of anthocyanins extracted from Oryza sativa L. in primary dermal fibroblasts. Oxid. Med. Cell. Longev. 2019, 2019, 2089817. [CrossRef]

161. Jacob, R.A.; Spinozzi, G.M.; Vicky, A.; Kelley, D.S.; Prior, R.L.; Hess-Pierce, B.; Kader, A.A. Consumption of cherries lowers plasma urate in healthy women. J. Nutr. 2003, 133, 1826-1829. [CrossRef] [PubMed]

162. Kelley, D.S.; Rasooly, R.; Jacob, R.A.; Kader, A.A.; Mackey, B.E. Consumption of Bing sweet cherries lowers circulating concentrations of inflammation markers in healthy men and women. J. Nutr. 2006, 136, 981-986. [CrossRef]

163. Beltrán-Debón, R.; Alonso-Villaverde, C.; Aragonès, G.; Rodríguez-Medina, I.; Rull, A.; Micol, V.; Segura-Carretero, A.; FernándezGutiérrez, A.; Camps, J.; Joven, J. The aqueous extract of Hibiscus sabdariffa calices modulates the production of monocyte chemoattractant protein-1 in humans. Phytomedicine 2010, 17, 186-191. [CrossRef]

164. Biedermann, L.; Mwinyi, J.; Scharl, M.; Frei, P.; Zeitz, J.; Kullak-Ublick, G.A.; Vavricka, S.R.; Fried, M.; Weber, A.; Humpf, H.U.; et al. Bilberry ingestion improves disease activity in mild to moderate ulcerative colitis-An open pilot study. J. Crohn's Colitis 2013, 7, 271-279. [CrossRef]

165. do Rosario, V.A.; Chang, C.; Spencer, J.; Alahakone, T.; Roodenrys, S.; Francois, M.; Weston-Green, K.; Hölzel, N.; Nichols, D.S.; Kent, K.; et al. Anthocyanins attenuate vascular and inflammatory responses to a high fat high energy meal challenge in overweight older adults: A cross-over, randomized, double-blind clinical trial. Clin. Nutr. 2020, 40, 879-889. [CrossRef]

166. Xia, M.; Ling, W.; Zhu, H.; Wang, Q.; Ma, J.; Hou, M.; Tang, Z.; Li, L.; Ye, Q. Anthocyanin prevents CD40-activated proinflammatory signaling in endothelial cells by regulating cholesterol distribution. Arterioscler. Thromb. Vasc. Biol. 2007, 27, 519-524. [CrossRef] [PubMed]

167. Seeram, N.P.; Momin, R.; Nair, M.G.; Bourquin, L.D. Cyclooxygenase inhibitory and antioxidant cyanidin glycosides in cherries and berries. Phytomedicine 2001, 8, 362-369. [CrossRef] [PubMed]

168. Vilkickyte, G.; Raudone, L.; Petrikaite, V. Phenolic fractions from Vaccinium vitis-idaea L. and their antioxidant and anticancer activities assessment. Antioxidants 2020, 9, 1261. [CrossRef]

169. Forbes-Hernández, T.Y.; Gasparrini, M.; Afrin, S.; Cianciosi, D.; González-Paramás, A.M.; Santos-Buelga, C.; Mezzetti, B.; Quiles, J.L.; Battino, M.; Giampieri, F.; et al. Strawberry (cv. Romina) methanolic extract and anthocyanin-enriched fraction improve lipid profile and antioxidant status in HepG2 cells. Int. J. Mol. Sci. 2017, 18, 1149. [CrossRef]

170. Masci, A.; Coccia, A.; Lendaro, E.; Mosca, L.; Paolicelli, P.; Cesa, S. Evaluation of different extraction methods from pomegranate whole fruit or peels and the antioxidant and antiproliferative activity of the polyphenolic fraction. Food Chem. 2016, 202, 59-69. [CrossRef]

171. Lage, N.N.; Anne, M.; Layosa, A.; Arbizu, S.; Chew, B.P.; Pedrosa, M.L.; Mertens-Talcott, S.; Talcott, S.; Noratto, G.D. Dark sweet cherry (Prunus avium) phenolics enriched in anthocyanins exhibit enhanced activity against the most aggressive breast cancer subtypes without toxicity to normal breast cells. J. Funct. Foods 2020, 64, 103710. [CrossRef]

172. Hogan, S.; Chung, H.; Zhang, L.; Li, J.; Lee, Y.; Dai, Y.; Zhou, K. Antiproliferative and antioxidant properties of anthocyanin-rich extract from açai. Food Chem. 2010, 118, 208-214. [CrossRef]

173. Long, H.L.; Zhang, F.F.; Wang, H.L.; Yang, W.S.; Hou, H.T.; Yu, J.K.; Liu, B. Mulberry anthocyanins improves thyroid cancer progression mainly by inducing apoptosis and autophagy cell death. Kaohsiung J. Med. Sci. 2018, 34, 255-262. [CrossRef]

174. Lee, J.Y.; Jo, Y.; Shin, H.; Lee, J.; Chae, S.U.; Bae, S.K.; Na, K. Anthocyanin-fucoidan nanocomplex for preventing carcinogen induced cancer: Enhanced absorption and stability. Int. J. Pharm. 2020, 586, 119597. [CrossRef]

175. Sousa, C.; Moita, E.; Valentão, P.; Fernandes, F.; Monteiro, P.; Andrade, P.B. Effects of colored and noncolored phenolics of Echium plantagineum L. bee pollen in Caco-2 cells under oxidative stress induced by tert -butyl hydroperoxide. J. Agric. Food Chem. 2015, 63, 2083-2091. [CrossRef]

176. Simas Frauches, N.; Montenegro, J.; Amaral, T.; Abreu, J.P.; Laiber, G.; Junior, J.; Borguini, R.; Santiago, M.; Pacheco, S.; Nakajima, V.M.; et al. Antiproliferative activity on human colon adenocarcinoma cells and in vitro antioxidant effect of anthocyanin-rich extracts from peels of species of the Myrtaceae family. Molecules 2021, 26, 564. [CrossRef]

177. Stoner, G.D.; Wang, L.-S. Chemoprevention of esophageal squamous cell carcinoma with berries. Top. Curr. Chem. 2013, 329, 1-20. [PubMed]

178. Stonera, G.D.; Wanga, L.-S.; Zikrib, N.; Chenc, T.; Hechtd, S.S.; Huang, C.; Sardoc, C.; Lechner, J.F. Cancer prevention with freeze-dried berries and berry components. Semin. Cancer Biol. 2008, 17, 403-410. [CrossRef] [PubMed]

179. Lippert, E.; Ruemmele, P.; Obermeier, F.; Goelder, S.; Kunst, C.; Rogler, G.; Dunger, N.; Messmann, H.; Hartmann, A.; Endlicher, E. Anthocyanins prevent colorectal cancer development in a mouse model. Digestion 2017, 95, 275-280. [CrossRef]

180. Kim, M.J.; Paramanantham, A.; Lee, W.S.; Yun, J.W.; Chang, S.H.; Kim, D.C.; Park, H.S.; Choi, Y.H.; Kim, G.S.; Ryu, C.H.; et al. Anthocyanins derived from Vitis coignetiae Pulliat contributes anti-cancer effects by suppressing NF-kB pathways in Hep3B human hepatocellular carcinoma cells and In Vivo. Molecules 2020, 25, 5445. [CrossRef] 
181. Aqil, F.; Jeyabalan, J.; Kausar, H.; Munagala, R.; Singh, I.P.; Gupta, R. Lung cancer inhibitory activity of dietary berries and berry polyphenolics. J. Berry Res. 2016, 6, 105-114. [CrossRef]

182. Chen, P.-N.; Chu, S.-C.; Chiou, H.-L.; Chiang, C.-L.; Yang, S.-F.; Hsieh, Y.-S. Cyanidin 3-glucoside and peonidin 3-glucoside inhibit tumor cell growth and induce apoptosis in vitro and suppress tumor growth in vivo. Nutr. Cancer 2005, 53, 232-243. [CrossRef]

183. Hafeez, B.; Siddiqui, I.A.; Asim, M.; Malik, A.; Afaq, F.; Adhami, V.M.; Saleem, M.; Din, M.; Mukhtar, H. A dietary anthocyanidin delphinidin induces apoptosis of human prostate cancer PC3 cells in vitro and in vivo: Involvement of nuclear factor- $\mathrm{kB}$ signaling. Cancer Res. 2008, 68, 8564-8572. [CrossRef]

184. Ha, U.S.; Bae, W.J.; Kim, S.J.; Yoon, B.I.; Hong, S.H.; Lee, J.Y.; Hwang, T.K.; Hwang, S.Y.; Wang, Z.; Kim, S.W. Anthocyanin induces apoptosis of du-145 cells in vitro and inhibits xenograft growth of prostate cancer. Yonsei Med. J. 2015, 56, 16-23. [CrossRef] [PubMed]

185. Hui, C.; Bin, Y.; Xiaoping, Y.; Long, Y.; Chunye, C.; Mantian, M.; Wenhua, L. Anticancer activities of an anthocyanin-rich extract from black rice against breast cancer cells in vitro and in vivo. Nutr. Cancer 2010, 62, 1128-1136. [CrossRef]

186. Liu, W.; Xu, J.; Liu, Y.; Yu, X.; Tang, X.I.; Wang, Z.H.I.; Li, X.I.N. Anthocyanins potentiate the activity of trastuzumab in human epidermal growth factor receptor 2-positive breast cancer cells in vitro and in vivo. Mol. Med. Rep. 2014, 10, 1921-1926. [CrossRef] [PubMed]

187. Condello, M.; Pellegrini, E.; Spugnini, E.P.; Baldi, A.; Amadio, B.; Vincenzi, B.; Occhionero, G.; Delfine, S.; Mastrodonato, F.; Meschini, S. Anticancer activity of "Trigno M", extract of Prunus spinosa drupes, against in vitro 3D and in vivo colon cancer models. Biomed. Pharmacother. 2019, 118, 109281. [CrossRef] [PubMed]

188. Fan, M.J.; Yeh, P.H.; Lin, J.P.; Huang, A.C.; Lien, J.C.; Lin, H.Y.; Chung, J.G. Anthocyanins from black rice (Oryza sativa) promote immune responses in leukemia through enhancing phagocytosis of macrophages in vivo. Exp. Ther. Med. 2017, 14, 59-64. [CrossRef]

189. Razina, T.G.; Zueva, E.P.; Ulrich, A.V.; Rybalkina, O.Y.; Chaikovskii, A.V.; Isaikina, N.V.; Kalinkina, G.I.; Zhdanov, V.V.; Zyuz'Kov, G.N. Antitumor effects of Sorbus aucuparia L. extract highly saturated with anthocyans and their mechanisms. Bull. Exp. Biol. Med. 2016, 162, 93-97. [CrossRef]

190. Kresty, L.A.; Mallery, S.R.; Stoner, G.D. Black raspberries in cancer clinical trials: Past, present and future. J. Berry Res. 2016, 6, 251-261. [CrossRef] [PubMed]

191. Lazzè, M.C.; Savio, M.; Pizzala, R.; Cazzalini, O.; Perucca, P.; Scovassi, A.I.; Stivala, L.A.; Bianchi, L. Anthocyanins induce cell cycle perturbations and apoptosis in different human cell lines. Carcinogenesis 2004, 25, 1427-1433. [CrossRef]

192. Ma, H.; Johnson, S.L.; Liu, W.; Dasilva, N.A.; Meschwitz, S.; Dain, J.A.; Seeram, N.P. Evaluation of polyphenol anthocyaninenriched extracts of blackberry, black raspberry, blueberry, cranberry, red raspberry, and strawberry for free radical scavenging, reactive carbonyl species trapping, anti-glycation, anti- $\beta$-amyloid aggregation, and mic. Int. J. Mol. Sci. 2018, 19, 461. [CrossRef]

193. Strathearn, K.E.; Yousef, G.G.; Grace, M.H.; Roy, S.L.; Tambe, M.A.; Ferruzzi, M.G.; Wu, Q.; Simon, J.E.; Ann, M.; Rochet, J.-C. Neuroprotective effects of anthocyanin- and proanthocyanidin-rich extracts in cellular models of Parkinson's disease. Brain Res. 2014, 1555, 60-77. [CrossRef]

194. Ullah, I.; Park, H.Y.; Kim, M.O. Anthocyanins protect against kainic acid-induced excitotoxicity and apoptosis via ROS-activated AMPK pathway in hippocampal neurons. CNS Neurosci. Ther. 2014, 20, 327-338. [CrossRef]

195. Whyte, A.R.; Cheng, N.; Fromentin, E.; Williams, C.M. A randomized, double-blinded, placebo-controlled study to compare the safety and efficacy of low dose enhanced wild blueberry powder and wild blueberry extract (ThinkBlue ${ }^{\mathrm{TM}}$ ) in maintenance of episodic and working memory in older adults. Nutrients 2018, 10, 660. [CrossRef] [PubMed]

196. Bendokas, V.; Stanys, V.; Mažeikienè, I.; Trumbeckaite, S.; Baniene, R.; Liobikas, J. Anthocyanins: From the field to the antioxidants in the body. Antioxidants 2020, 9, 819. [CrossRef] [PubMed]

197. Asgary, S.; Kelishadi, R.; Rafieian-Kopaei, M.; Najafi, S.; Najafi, M.; Sahebkar, A. Investigation of the lipid-modifying and antiinflammatory effects of Cornus mas L. supplementation on dyslipidemic children and adolescents. Pediatr. Cardiol. 2013, 34, 1729-1735. [CrossRef]

198. Noordin, L.; Wan Mohamad Noor, W.N.I.; Safuan, S.; Wan Ahmad, W.A.N. Therapeutic effects of anthocyanin-rich Hibiscus sabdariffa L. extract on body mass index, lipid profile and fatty liver in obese-hypercholesterolaemic rat model. Int. J. Basic Clin. Pharmacol. 2019, 9, 1. [CrossRef]

199. Güder, A.; Gür, M.; Engin, M.S. Antidiabetic and antioxidant properties of bilberry (Vaccinium myrtillus Linn.) fruit and their chemical composition. J. Agric. Sci. Technol. 2015, 17, 401-414.

200. Akkarachiyasit, S.; Yibchok-Anun, S.; Wacharasindhu, S.; Adisakwattana, S. In vitro inhibitory effects of cyanidin-3-rutinoside on pancreatic $\alpha$-amylase and its combined effect with acarbose. Molecules 2011, 16, 2075-2083. [CrossRef]

201. Khan, M.I.; Shin, J.H.; Shin, T.S.; Kim, M.Y.; Cho, N.J.; Kim, J.D. Anthocyanins from Cornus kousa ethanolic extract attenuate obesity in association with anti-angiogenic activities in 3T3-L1 cells by down-regulating adipogeneses and lipogenesis. PLoS ONE 2018, 13, e0208556. [CrossRef]

202. Adisakwattana, S.; Yibchok-Anun, S.; Charoenlertkul, P.; Wongsasiripat, N. Cyanidin-3-rutinoside alleviates postprandia hyperglycemia and its synergism with acarbose by inhibition of intestinal $\alpha$-glucosidase. J. Clin. Biochem. Nutr. 2011, $49,36-41$. [CrossRef] [PubMed]

203. Liu, Y.; Li, D.; Zhang, Y.; Sun, R.; Xia, M. Anthocyanin increases adiponectin secretion and protects against diabetes-related endothelial dysfunction. Am. J. Physiol. Endocrinol. Metab. 2014, 306, 975-988. [CrossRef] 
204. Wu, T.; Jiang, Z.; Yin, J.; Long, H.; Zheng, X. Anti-obesity effects of artificial planting blueberry (Vaccinium ashei) anthocyanin in high-fat diet- treated mice. Int. J. Food Sci. Nutr. 2016, 67, 257-264. [CrossRef]

205. Wu, T.; Liu, R. Anthocyanins in black rice, soybean and purple corn increase fecal butyric acid and prevent liver inflammation in high fat diet-induced obese mice. Food Funct. 2017, 8, 3178-3186. [CrossRef]

206. Liu, Y.; Tan, D.; Shi, L.; Liu, X.; Zhang, Y.; Tong, C.; Song, D.; Hou, M. Blueberry anthocyanins-enriched extracts attenuate cyclophosphamide-induced cardiac injury. PLoS ONE 2015, 10, 1-18. [CrossRef]

207. Song, F.; Zhu, Y.; Shi, Z.; Tian, J.; Deng, X.; Ren, J.; Andrews, M.C.; Ni, H.; Ling, W.; Yang, Y. Plant food anthocyanins inhibit platelet granule secretion in hypercholesterolaemia: Involving the signalling pathway of PI3K-Akt. Thromb. Haemost. 2014, 112, 981-991. [CrossRef] [PubMed]

208. Matsunaga, N.; Tsuruma, K.; Shimazawa, M.; Yokota, S.; Hara, H. Inhibitory actions of bilberry anthocyanidins on angiogenesis. Phyther. Res. 2009, 24, S42-S47. [CrossRef] [PubMed]

209. Gaiz, A.; Kundur, A.R.; Colson, N.; Shibeeb, S.; Singh, I. Assessment of in vitro effects of anthocyanins on platelet function. Altern. Ther. Health Med. 2020, 26, 12-17. [PubMed]

210. Hassellund, S.S.; Flaa, A.; Kjeldsen, S.E.; Seljeflot, I.; Karlsen, A.; Erlund, I.; Rostrup, M. Effects of anthocyanins on cardiovascular risk factors and inflammation in pre-hypertensive men: A double-blind randomized placebo-controlled crossover study. J. Hum. Hypertens. 2013, 27, 100-106. [CrossRef]

211. McAnulty, L.S.; Collier, S.R.; Landram, M.J.; Whittaker, D.S.; Isaacs, S.E.; Klemka, J.M.; Cheek, S.L.; Arms, J.C.; McAnulty, S.R. Six weeks daily ingestion of whole blueberry powder increases natural killer cell counts and reduces arterial stiffness in sedentary males and females. Nutr. Res. 2014, 34, 577-584. [CrossRef]

212. Habanova, M.; Saraiva, J.A.; Haban, M.; Schwarzova, M.; Chlebo, P.; Predna, L.; Gažo, J.; Wyka, J. Intake of bilberries (Vaccinium myrtillus L.) reduced risk factors for cardiovascular disease by inducing favorable changes in lipoprotein profiles. Nutr. Res. 2016, 36, 1415-1422. [CrossRef]

213. Arevström, L.; Bergh, C.; Landberg, R.; Wu, H.; Rodriguez-Mateos, A.; Waldenborg, M.; Magnuson, A.; Blanc, S.; Fröbert, O. Freeze-dried bilberry (Vaccinium myrtillus) dietary supplement improves walking distance and lipids after myocardial infarction: An open-label randomized clinical trial. Nutr. Res. 2019, 62, 13-22. [CrossRef]

214. Draijer, R.; de Graaf, Y.; Slettenaar, M.; de Groot, E.; Wright, C.I. Consumption of a polyphenol-rich grape-wine extract lowers ambulatory blood pressure in mildly hypertensive subjects. Nutrients 2015, 7, 3138-3153. [CrossRef]

215. Igwe, E.O.; Charlton, K.E.; Roodenrys, S.; Kent, K.; Fanning, K.; Netzel, M.E. Anthocyanin-rich plum juice reduces ambulatory blood pressure but not acute cognitive function in younger and older adults: A pilot crossover dose-timing study. Nutr. Res. 2017, 47, 28-43. [CrossRef]

216. Xie, L.; Vance, T.; Kim, B.; Lee, S.G.; Caceres, C.; Wang, Y.; Hubert, P.A.; Lee, J.Y.; Chun, O.K.; Bolling, B.W. Aronia berry polyphenol consumption reduces plasma total and low-density lipoprotein cholesterol in former smokers without lowering biomarkers of inflammation and oxidative stress: A randomized controlled trial. Nutr. Res. 2017, 37, 67-77. [CrossRef] [PubMed]

217. Bakkar, Z.A.; Fulford, J.; Gates, P.E.; Jackman, S.R.; Jones, A.M.; Bond, B.; Bowtell, J.L. Montmorency cherry supplementation attenuates vascular dysfunction induced by prolonged forearm occlusion in overweight, middle-aged men. J. Appl. Physiol. 2019, 126, 246-254. [CrossRef] [PubMed]

218. Bell, L.; Lamport, D.J.; Butler, L.T.; Williams, C.M. A study of glycaemic effects following acute anthocyanin-rich blueberry supplementation in healthy young adults. Food Funct. 2017, 8, 3104-3110. [CrossRef] [PubMed]

219. Zhu, Y.; Xia, M.; Yang, Y.; Liu, F.; Li, Z.; Hao, Y.; Mi, M.; Jin, T.; Ling, W. Purified anthocyanin supplementation improves endothelial function via NO-cGMP activation in hypercholesterolemic individuals. Clin. Chem. 2011, 57, 1524-1533. [CrossRef]

220. Kianbakht, S.; Abasi, B.; Hashem Dabaghian, F. Improved lipid profile in hyperlipidemic patients taking vaccinium arctostaphylos fruit hydroalcoholic extract: A randomized double-blind placebo-controlled clinical trial. Phyther. Res. 2014, 28, 432-436. [CrossRef]

221. Cook, M.D.; Myers, S.D.; Gault, M.L.; Willems, M.E.T. Blackcurrant alters physiological responses and femoral artery diameter during sustained isometric contraction. Nutrients 2017, 9, 556. [CrossRef] [PubMed]

222. Milbury, P.E.; Graf, B.; Curran-Celentano, J.M.; Blumberg, J.B. Bilberry (Vaccinium myrtillus) anthocyanins modulate heme oxygenase-1 and glutathione S-transferase-pi expression in ARPE-19 cells. Investig. Ophthalmol. Vis. Sci. 2007, 48, 2343-2349. [CrossRef] [PubMed]

223. Sundalius, N.M. Examination of Blueberry Anthocyanins in Prevention of Age-Related Macular Degeneration through Retinal Pigment Epithelial Cell Culture Study; Louisiana State University and Agricultural and Mechanical College: Baton Rouge, LA, USA, 2008.

224. Matsumoto, H.; Kamm, K.E.; Stull, J.T.; Azuma, H. Delphinidin-3-rutinoside relaxes the bovine ciliary smooth muscle through activation of ETB receptor and NO/cGMP pathway. Exp. Eye Res. 2005, 80, 313-322. [CrossRef]

225. Iida, H.; Nakamura, Y.; Matsumoto, H.; Takeuchi, Y.; Harano, S.; Ishihara, M.; Katsumi, O. Effect of black-currant extract on negative lens-induced ocular growth in chicks. Ophthalmic Res. 2010, 44, 242-250. [CrossRef] [PubMed]

226. Nakaishi, H.; Matsumoto, H.; Tominaga, S.; Hirayama, M. Effects of black currant anthocyanoside intake on dark adaptation and VDT work-induced transient refractive alteration in healthy humans. Altern. Med. Rev. 2000, 5, 553-562. [PubMed] 